\title{
Strain localized deformation variation of a small-scale ductile shear zone
} Lefan Zhan ${ }^{1}$, Shuyun Cao*1, Yanlong Dong ${ }^{1}$, Wenyuan $\mathrm{Li}^{1}$

${ }^{1}$ State Key Laboratory of Geological Processes and Mineral Resources, China University of Geosciences, Wuhan 430074, China

Correspondence: Shuyun Cao (Shuyun.cao@cug.edu.cn)

\section{Abstract:}

A continental-scale strike-slip shear zone frequently presents a long-lasting deformation and physical expression of strain localization in a middle to lower crustal level. However, the deformation evolution of strain localization at a small-scale shear zone remains unclear. This study investigated $<10 \mathrm{~cm}$ wide shear zones developing in undeformed granodiorites exposed at the boundary of the continental-scale Gaoligong strike-slip shear zone. The small-scale ductile shear zone demonstrated a typical transition from protomylonite, mylonite to extremely deformed ultramylonite, and decreased mineral size from coarse-grained aggregates to extremely fine-grained mixed phase. Shearing senses such as hornblende and feldspar porphyroclasts in the shear zone are the more significantly low-strain zone of mylonite. The microstructure and EBSD results revealed that the small-scale shear zone experienced ductile deformation under medium-high temperature conditions. Quartz aggregates suggested a consistent temperature with an irregular feature, exhibiting a dominated high-temperature prism $<\mathrm{a}>$ slip system. Additionally, coarse-grained aggregates in the mylonite of the shear zone were deformed predominantly by dislocation creep, while ultra-plastic flow by viscous grain boundary sliding was an essential deformation process in the extremely finegrained $(\sim 50 \mu \mathrm{m})$ mixed-phase of ultramylonite. Microstructural-derived strain rates calculated from quartz paleopiezometry were on the order of $10^{-15}$ to $10^{-13} \mathrm{~s}^{-1}$ from lowstrain mylonite to high strained ultramylonite. The localization and strain rate-limited process was fluid-assisted precipitation presenting transitions of compositions as hydrous retrogression of hornblende to mica during increasing deformation and exhumation. Furthermore, the potential occurrence of the small-scale shear zone was initiated at a deep-seated crustal dominated by the temperature-controlled formation and rheological weakening.

Keywords: strain localization, ductile deformation, ultramylonite, microstructure, EBSD texture, Gaoligong shear zone

\section{Introduction}

Many previous studies (e.g., field analysis, laboratory experiments, numerical 
modeling, seismology, hydrogeology) have focused on describing and discussing the architecture, initiation mechanisms, and rock failure processes of the shear zone (Sibson, 1977; Scholz, 1980, 1989; Wintsch et al., 1995; Tikoff and de Saint Blanquat, 1997; Brown and Solar, 1998; Rosenberg, 2004; Mancktelow, 2008; Wibberley et al., 2008; Frost et al., 2011; Mancktelow and Pennacchioni, 2013; Cao and Neubauer, 2016; Fossen and Cavalcante, 2017; Menegon et al., 2017; Vannucchi, 2019; Fagereng and Beall, 2021). The shear zone is known that strain localizes into the tabular zone from small outcrop-size individual zone to large composite structure in the large-scale in the lithosphere (Fossen and Cavalcante, 2017). The continental-scale strike-slip shear zone commonly appears as long-standing zones of weakness in the crust, which extend across ductile lower crust (shear zone) through the brittle-ductile transition into brittle crust (fault zone) (Sibson, 1977; Scholz, 1980, 1989). The exhumed strike-slip shear zones at depth are crucial structural borders within or between major continental blocks influenced by lateral extrusion, recording the strain localization and regional kinematic history (Ratschbacher et al., 1991; Cunningham and Mann, 2007; Cao and Neubauer, 2016). Besides, nucleation and initiation of a continental-scale shear zone occur within the deep crust or even mantle lithosphere in a specific thermal-structural architecture, where temperature-controlled rheological weakening plays a critical role in localizing future strike-slip shear zone (Cao and Neubauer, 2016 and references therein). Although numerous studies have established the small-scale $\left(10^{-3}-10^{-1} \mathrm{~m}\right.$ thick) ductile shear zones within massive host rocks, the distribution and significance of shear localization at small scales are controversial (e.g., Bons and Jessell, 1999; Mancktelow and Pennacchioni, 2005, 2020; Pennacchioni, 2005; Menegon and Pennacchioni, 2009; Pennacchioni and Zucchi, 2013; Pennacchioni and Mancktelow, 2018; Ceccato et al., 2020).

Experiments and models on the deformation of rocks have been proposed to explain the formation of shear zones in varied scales, including the lithosphere's strength, the external conditions such as temperature, pressure, and fluid content, and the fact that rocks' rheology depends on their composition and grain size (e.g., Evans, 2000; Faulkner and Rutter, 2001; Collettini et al., 2009; Bense et al., 2013; Cao and Neubauer, 2016; Fossen and Cavalcante, 2017; Liu, 2017). It is suggested that the small individual zones can grow into the large and composite shear zone networks by segment linkage as they accumulate strain and displacement (Pennacchioni, 2005; Vauchez et al., 2007; Ganade de Araujo et al., 2014; Fossen and Cavalcante, 2017). The case from the field-based study is inconsistent with argues the nucleation model of the shear zone by strain localization in a homogeneous rheological media based on random distributions of weak particles or through the dilation of the wing veins on either the compressed or extensional side (Mancktelow, 2002, 2008; Misra and Mandal, 2007; Wehrens et al., 2016; Nevitt and 
Pollard, 2017; Nevitt et al., 2017; Pennacchioni and Mancktelow, 2018). Besides, the initial composition changes with fluid infiltration along and diffusion away from the discontinuities as pre-existing brittle fractures, bringing high significance to the types of developing shear zone (Mancktelow and Pennacchioni, 2005; Pennacchioni, 2005; Pennacchioni and Zucchi, 2013; Pennacchioni and Mancktelow, 2018). However, ongoing deformation and metamorphism can obliterate or reset any traces of such smallscale localization (Bons and Jessell, 1999). Therefore, the processes and mechanism of localizing in a small-scale shear zone are still unclear.

This study presents a detailed description of small-scale shear zones developing in unfoliated large intrusive granodiorite bodies at the boundary of the Gaoligong continental-scale shear zone (GLG-SZ) on the southeastern margin of the Tibetan Plateau. The new detail microstructural, EBSD texture, and geothermal data reveal that (1) strain localization in small-scale shear zones is characterized by the development of mylonite and ultramylonite with the increasing strain from rim to the center, (2) formation conditions and processes of the micro-shear zone are associated with the continentalscale GLG-SZ ductile shearing and exhumation.

\section{Geological setting and field description}

The southeastern margin of the Tibetan Plateau has been engaged in crustal thickening, tectonic compression, block rotation, and strike-slip shearing during the Cenozoic (Tapponnier and Molnar, 1977; Tapponnier et al., 1982, 1990) (Fig. 1). Several continental-scale strike-slip shear zones including the Gaoligong shear zone (GLG-SZ), the Chongshan-Biluoxueshan shear zone, and the Ailaoshan-Red River shear zone are developed in the Sanjiang region (Jinshajiang, Lancangjiang, and Nujiang) (Fig. 1). The formation of these strike-slip shear zones has been attributed to the Cenozoic continental collision of the India and Eurasia plates. The GLG-SZ is a narrow N-S trending belt with a width of 10 kilometers and a length of 600 kilometers, extending southward from the eastern Himalayan Syntaxis to the eastern Tengchong area and then extending southwestward to join the Sagaing fault zone (Fig. 1B). It serves as the boundary between the Tengchong and Baoshan blocks (Ji et al., 2000a; Zhang et al., 2012a, b; Liu et al., 2017; Dong et al., 2019; Tang et al., 2020). The Cambrian gneiss and the Neoproterozoic metamorphic units, named the Gaoligong metamorphic complex, represent the basement units in this area and evolve into the Gaoligong strike-slip shear zone along after the reactivation in Cenozoic (Wang et al., 2006; Wang et al., 2008; Zhang et al., 2012b; Zhu et al., 2017; Dong et al., 2019) (Fig. 1B). The main rock types are mylonitic gneisses (granitic gneisses and migmatitic gneisses) and schists, as well as amphibolites and marbles.

Along the GLG-SZ, a considerable number of Mesozoic and Cenozoic granitic rocks intrude into the Gaoligong metamorphic complex (Wang et al., 2006; Zhang et al., 
2018; Dong et al., 2019) (Fig. 1B). Recent zircon U-Pb and ${ }^{39} \mathrm{Ar} /{ }^{40} \mathrm{Ar}$ chronological data revealed that both of the unfoliated and foliated granitic intrusions in the northwest part of the GLG-SZ has the emplaced ages of 112-125 Ma (Early Cretaceous) during the collision of the Lhasa and the Qiangtang blocks, post-magmatic melting timing of ca. 35 Ma (Early Oligocene), and subsequent cooling during the Middle Miocene (ca. $13 \mathrm{Ma}$ ) (Xu et al., 2012; Zhu et al., 2017; Dong et al., 2021). Two-stage tectono-thermal evolutions since the Late Cretaceous have also been proposed. Around 76-74 Ma, earlier regional metamorphism occurs in the high-pressure granulite facies owing to crustal thickening and magmatism. Around 24-23 Ma, the later stage was defined by amphibolite-greenschist facies conditions in connection with shearing deformation (Ji et al., 2000b; Song et al., 2010). The analysis of geochronological data from the Tengchong area suggests that the dome uplift and deep crustal material was exhumed during 32-10 Ma in the south of the GLG-SZ (Xu et al., 2015; Zhang et al., 2017; Dong et al., 2019).

Within the GLG-SZ, the high-grade rocks and most of the granitic intrusions within the GLG-SZ underwent the Cenozoic deformation of right-lateral strike-slip shear (Zhang et al., 2012b; Xu et al., 2015; Liu et al., 2017; Chiu et al., 2018; Dong et al., 2019) (Fig. 2A, B). The rocks demonstrate dominated characteristics of ductile deformation structures, including asymmetric folds, highly developed mylonitic lineation, finegrained minerals, S-C fabrics, and shear bands (Dong et al., 2019). All shear sense indicators of $\sigma$ - and $\delta$-porphyroclasts (Figs. 2A, B), as well as S-C fabrics and asymmetric folds, exhibit strong dextral shear. Mylonites are characterized with $\mathrm{L}>>\mathrm{S}-$ type structures, in which the mineral stretching lineation is far more developed than mylonitic foliation (Fig. 2B). The foliation runs approximate $\mathrm{N}-\mathrm{S}$ trending and dips moderately to steeply to the east $\left(27-78^{\circ}\right)$, while the lineation slightly dips to the north or south $\left(<23^{\circ}\right)$ (Fig. 1C; Dong et al., 2019).

This study emphasizes the small-scale shear zones newly observed within the unfoliated granidiorite at the western part of the GLG-SZ. The magmatic fabric of granidiorite is deficient in solid-state ductile deformation features and presents randomly arranged feldspar phenocrysts (Fig. 2). The small-scale shear zones have a thickness of approximately $10^{-3}-10^{-1} \mathrm{~m}$. Most structures are steeply dipping, and the orientations are relatively disorderly (Fig. 1C). 
https://doi.org/10.5194/se-2022-2

Preprint. Discussion started: 25 January 2022

(c) Author(s) 2022. CC BY 4.0 License.

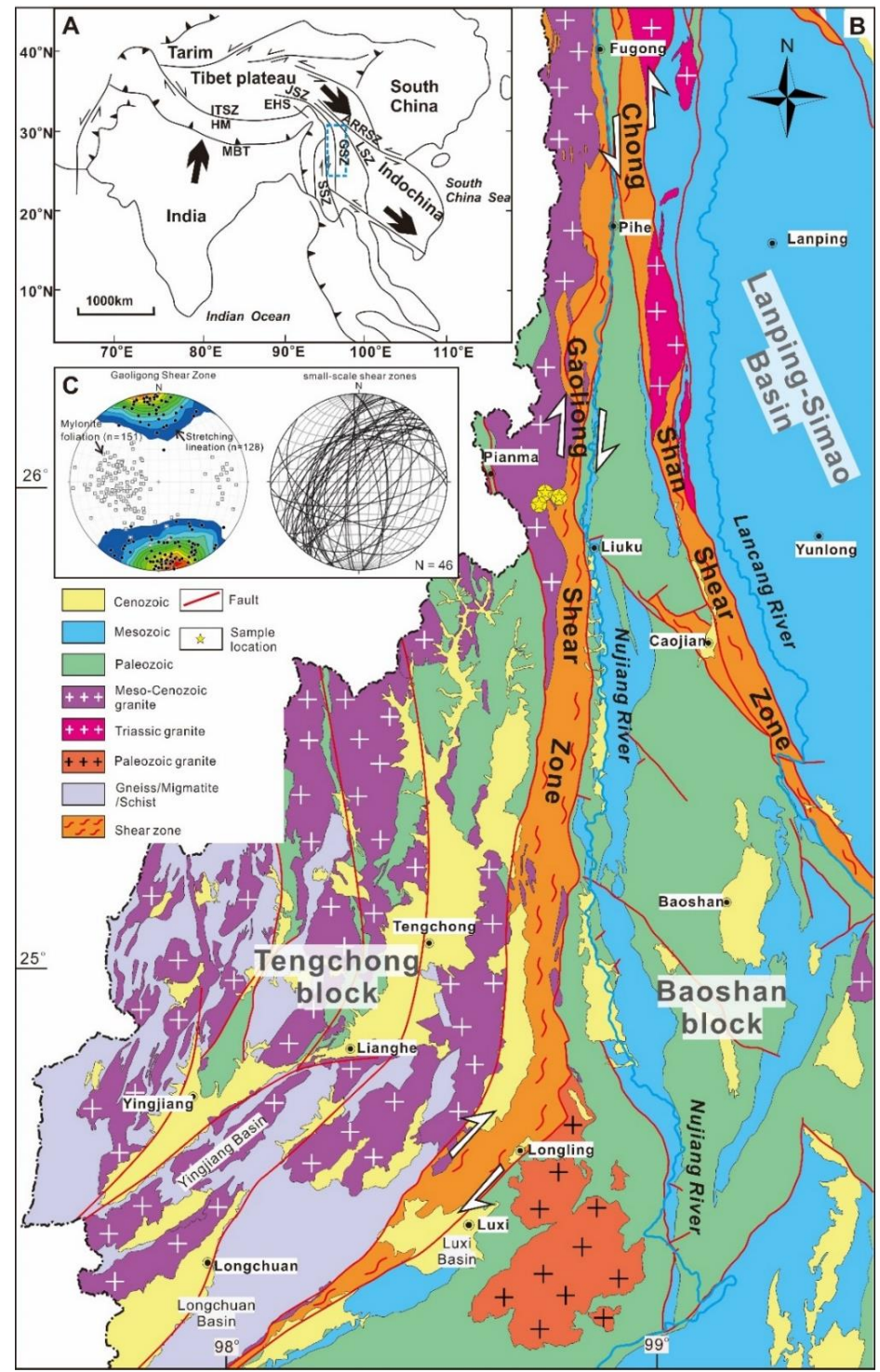

Fig. 1. The Geological maps of the San Jiang region and the Gaoligong shear zone. (A) Regional tectonic map of the India-Eurasian plate. (B) Simplified geological map of the San Jiang region modified from Wang et al., 2008 and Dong et al., 2021; (C) Foliation and lineation data for GLG-SZ and the strikings of small-scale shear zones, plotted in stereographic projection (lower hemisphere). ARRSZ: Ailaoshan-Red River Shear Zone; EHS: Eastern Himalayan Syntaxis; GLG-SZ: Gaoligong shear zone; CSZ: Chongshan Shear Zone; JSZ: Jiali Shear Zone; SF: Sagaing fault.

\section{Analytical methods}




\subsection{Microscopy and cathodoluminescence}

Microstructure and petrology in the small-scale shear zone and granidiorite rock were investigated in thin sections by optical and SEM, cathodoluminescence (CL) imaging, and electron backscatter diffraction (EBSD). A Sigma 300VP field emission scanning electron microscope (FEG-SEM) and BII CLF-2 Cathodoluminescence (CL) are employed in the China University of Geosciences (Wuhan). CL operated at a voltage of $15 \mathrm{KV}$, power consumption of $150 \mathrm{~W}$, a current of $300 \mathrm{~A}$, and a beam current of $1 \mathrm{~mA}$ with a diameter of $30 \mu \mathrm{m}$.

\subsection{Electron backscatter diffraction (EBSD)}

The Sigma 300VP FEG-SEM with a Symmetry EBSD (electron backscatter diffraction) detector in China University of Geosciences (Wuhan) was applied to obtain the mineral CPO. The highly polished thin sections with conductive tape attached to the surface were put in the SEM chamber and rotated at a $70^{\circ}$ tilt angle. Electron backscatter patterns were acquired using the automatic mapping mode under the conditions of low vacuum, with a detector distance of $193.1 \mathrm{~mm}$, an acceleration voltage of $20 \mathrm{kV}$, and a beam working distance of $15.6 \mathrm{~mm}$. Indexing is considered acceptable when at least six detected kikuchi bands correspond to those in the analyzed mineral phases' standard reflector file. Following the completion of the test, the electron backscatter pattern analysis was performed using the Aztec Crystal and HKL Channel 5. The pole figure of representative $\mathrm{CPO}$ in samples was plotted in equal-area stereographic diagrams using the lower hemisphere projection and the base circle represents the $\mathrm{X}-\mathrm{Z}$ plane parallel to the lineation and vertical to the foliation. Automated orientation maps revealed systematic not-indexing, and such data were replaced with zero solution pixels.

\subsection{EPMA methodology}

Compositional data of unfoliated granitoids and foliated granitic rocks were measured on a JEOL electron microprobe (JXA-8600) with a wavelength dispersive system at the Department of Geography and Geology, University of Salzburg. Measuring conditions using a focused electron beam involved a $15 \mathrm{kV}$ acceleration voltage and a $40 \mathrm{nA}$ sample current. The calibration of the microprobe was performed based on natural silicates and synthetic oxides standards. The matrix correction for quantitative analysis was conducted by the ZAF oxide method for most silicate minerals. The detection limits $(2 \sigma)$ are $0.06 \mathrm{wt}^{\%} \%$ and $0.04 \mathrm{wt} \%$ for $\mathrm{Si}$ and $\mathrm{Al}$, respectively, and are $0.025 \mathrm{wt} \%$ for $\mathrm{Na}$, $\mathrm{K}, \mathrm{Mg}, \mathrm{Mn}$, and Fe.

\section{Deformed characteristics of granodiorites and small-scale shear zones}

\subsection{Mesoscale structures of granodiorites and small-scale shear zones}

As mentioned above, the GLG-SZ exposed widespread granitic intrusions of various ages (Fig. 1B) (Zhang et al., 2017; Zhu et al., 2017; Chiu et al., 2018; Zhang et 
al., 2018; Tang et al., 2020; Dong et al., 2021). Most granitic intrusions underwent strong mylonitization within the GLG-SZ. Notably, the unfoliated granodiorites were exposed at the western boundary of the GLG-SZ. The major body of the studied granodiorites exhibits little macroscopic evidence of solid-state deformation-metamorphism, and igneous relationships are well preserved (Fig. 2C-H).

The granodiorites present strain localization on a network of different types of small-scale shear zones with a thickness of approximately $10^{-3}-10^{-1} \mathrm{~m}$. They are invariably localized on approximately planar structural and compositional heterogeneities within the protolith (Fig.2C, D). The small-scale shear zones exhibit significant ductile and/or brittle deformation characteristics. Regarding centimeter-scale or decimeter-scale shear zones, the strain is strongly localized in a narrow band, and minerals are elongated directionally in the outcrop scale (Fig.2C, D). Most structural and compositional heterogeneities demonstrate a nearly horizontal stretching lineation and extremely fine-grained minerals of ductile shearing. The enclaves occur in the granodiorites crosscut by isolated, knife-sharp ( $<1-3 \mathrm{~mm}$ wide) brittle fractures, and may have a strike length of many tens of meters (Fig. $2 \mathrm{G}$ ). The brittle fractures are typically identified by a dark biotite-rich slit. Most of these reflect displacement discontinuities in the outcrop scale. For example, cross-cut markers (e.g., mafic enclaves) are severely truncated and displaced by the shear zones without any dragging effect (Fig. 2G, H). Some display bands and several centimeters wide of a sigmoidal-shaped foliation of ductile shearing, implying a dextral sense of shear (Fig. 2F, H). 
https://doi.org/10.5194/se-2022-2

Preprint. Discussion started: 25 January 2022

(c) Author(s) 2022. CC BY 4.0 License.
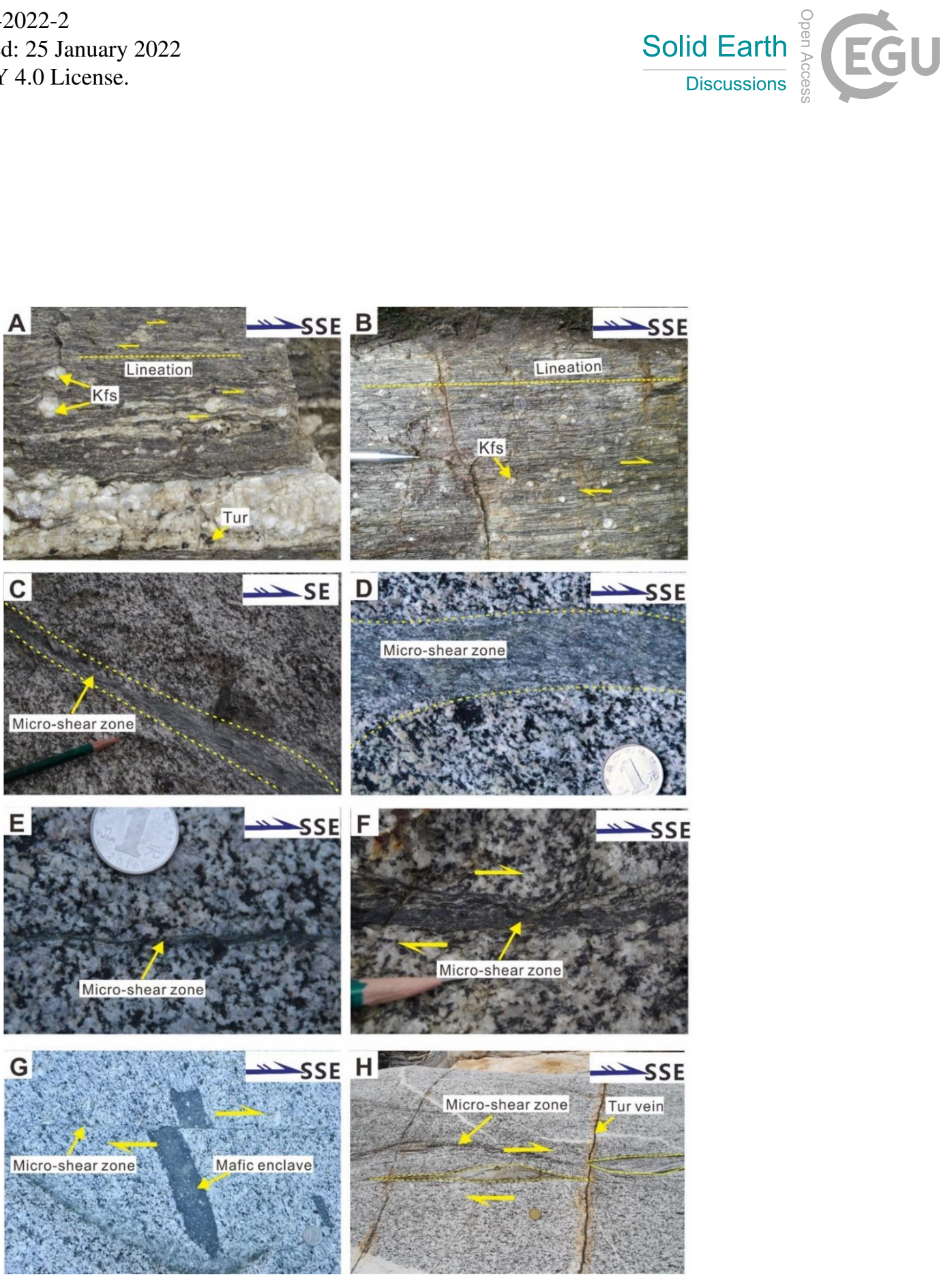

Fig.2. Field structures of the GLG-SZ and small-scale shear zones. (A)-(B) Some representative deformation structures of the GLG-SZ in the XZ plane (the plane parallel to the lineation and vertical to the foliation). (C)-(D) Ductile shear zones in the centimeter-scale/ decimeter-scale. (E) millimeter-scale ductile shear zones are like joints in the outcrop scale. $(F)$ millimeter-scale shear zones form a sigmoidal-shaped foliation at the shear zone boundaries. (G)-(H) Dextral offset of some crosscut markers across millimeter-scale shear zones.

\subsection{Microstructures of unfoliated granodiorite}


The unfoliated granodioritic host rocks are composed of quartz (16-19 vol\%), Kfeldspar (17-19 vol\%), plagioclase ( 59-63 vol\%), hornblende ( 7 vol\%), and biotite (2-3 vol\%). The unfoliated granodioritic exhibits little evidence of ductile deformation. Feldspar and hornblende grains both primarily consist of euhedral to subhedral coarse grains and form with microfracture (Fig. 3A). The coarse-grained feldspar grains are dominated by plagioclase and tiny amounts of K-feldspar. The plagioclase (up to several millimeters in length) has significant polysynthetic twinning and ring or zoning magma structure that grows fine-grained inclusions of biotite and quartz grains (Fig. 3A). The crystal sizes of hornblende are about $0.5-5 \mathrm{~mm}$, and the grains develop two groups of cleavages (Fig. 3B). Quartz grains present polycrystal aggregates, which are mostly xenomorphic around the plagioclase grains. The biotite grains demonstrate the features of an undeformed or only slightly bent shape with magmatic phase (Fig. 3C).

\subsection{Microstructures of the small-scale shear zone}

Under the microscope, the small-scale shear zone developing in the granodiorite has dramatical shearing banding, reflecting a transition deformation characteristic from protolith to ultramylonite. The mineral grain size gradually decreases from rim to center, with a strong strain gradient. According to the different grains size, three distinct deformed microstructure zones can be recognized (Fig. 3): Zone A with relatively close to the outer/rim low strain portions (Fig. 3D), high fine-grained Zone B of traversing into the shear zones, and strong fine-grained Zone $\mathrm{C}$ in the center of the shear zone.

Zone $\mathrm{A}$ in the small-scale shear zone is of the rim outer relative low strain portions, composed of plagioclase, K-feldspar, biotite, quartz, and a small amount of apatite. It presents the characteristics of protomylonite. The coarse-grained plagioclase, K-feldspar, and hornblende are well preserved. The fine-grained quartz grains form polycrystal aggregate ribbons. The borders of quartz grains exhibit various morphologies, ranging from slightly curved to serrated (Fig. 3C), suggesting characteristics of dynamic recrystallization by grain boundary migration (GBM). The large plagioclase grains develop mechanical twins and fractures locally. Some of the fractures of plagioclase crosscutting the grains are filled by quartz (Fig. 3C). 
https://doi.org/10.5194/se-2022-2

Preprint. Discussion started: 25 January 2022

(c) Author(s) 2022. CC BY 4.0 License.

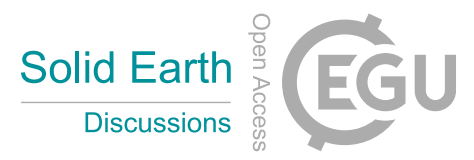

(c) (i)

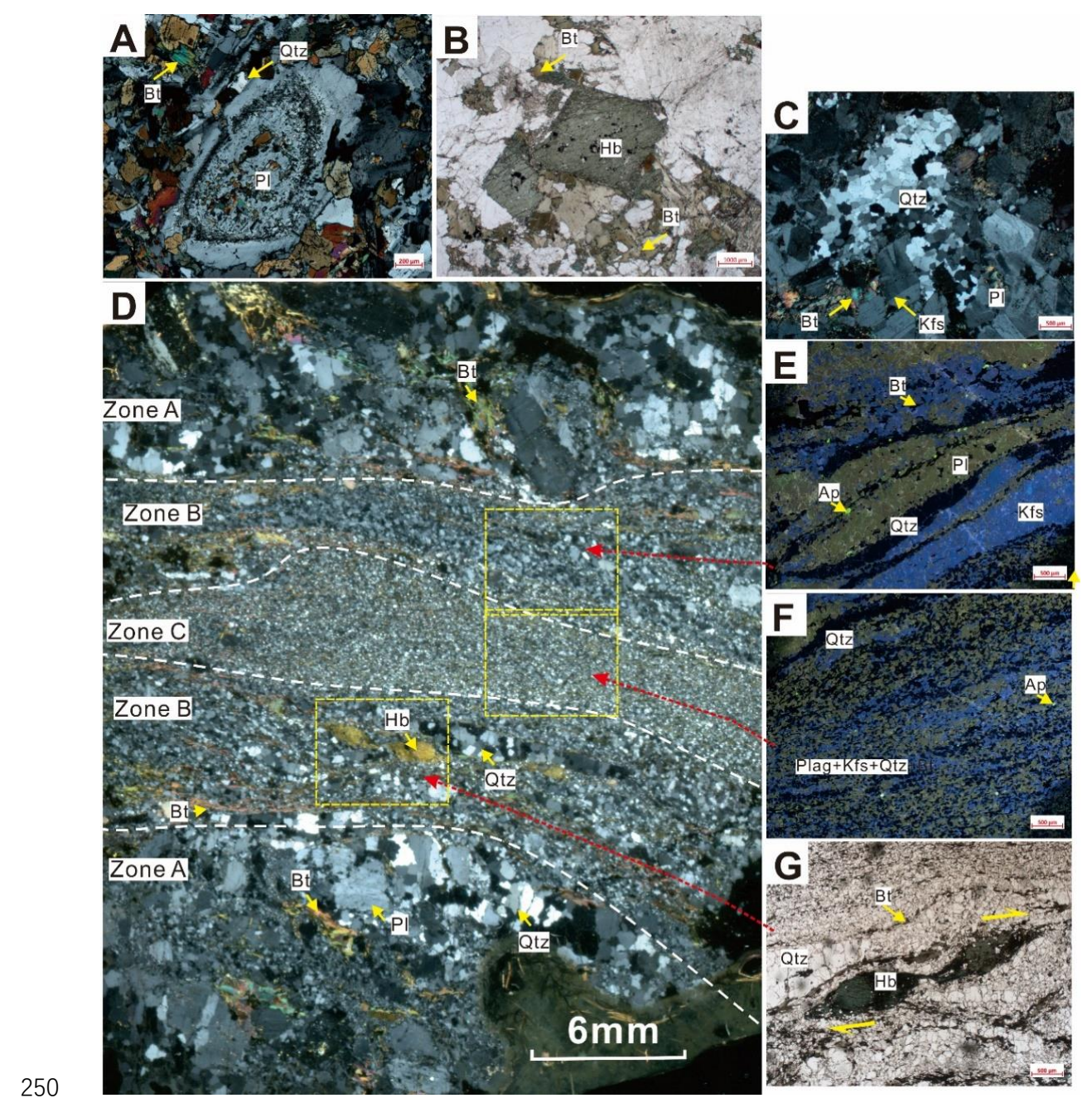

Fig.3. Microscopic deformation characteristics of unfoliated granodiorite and small-

252 scale shear zones. (A) Ring or zoned structure of plagioclase in the unfoliated 253 granodiorite. (B) The euhedral to subhedral hornblende crystals in the unfoliated 254 granodiorite s. (C) quartz-rich aggregates and feldspar porphyroclast with mechanical 255 twinning and fractures in the Zone A of shear zone. (D) Thin section scanning of small256 scale shear zone. (E) Fine-grained layers in the Zone B. (F) The mixed-phase zone in 257 the Zone $C$ of shear zone. (G) The residual hornblende grains indicating right-lateral 258 shearing in the Zone B of shear zone. Fig. (B), (G) are plane polarized light micrographs,

259 (A), (C) and (D) are cross-polarized light micrographs and (E), (F) are 260 cathodoluminescence (CL) images. Qtz: quartz, Pl: plagioclase, Kfs: K-feldspar, Bt: 261 biotite, $\mathrm{Hb}$ : hornblende, Ap: apatite. 
Under the SEM observation, the BSE images reveal a characteristic core-mantle structure in the K-feldspar porphyroclasts surrounded by fine grains or subgrains (Fig. 4A, average length $760 \mu \mathrm{m}$ ). The long axes of porphyroclasts are parallel or oblique to the shear zone. Myrmekites develop at the rim of the K-feldspar porphyroclasts. Neocrystallization quartz grains (average length $45 \mu \mathrm{m}$, Fig 4B) within myrmekites are elongated vertical to the long axis of K-feldspar porphyroclasts. Neocrystallization plagioclase grains (average length of $\sim 60 \mu \mathrm{m}$ ) within the myrmekites are equiaxed. The fine-grained quartz and plagioclase grains nucleate around $\mathrm{K}$-feldspar porphyroclasts (Fig. 4A, B). The mica grains (average length $10 \mu \mathrm{m}$ ) are long-prismatic and plateprismatic, slenderer than these in the main body of granodiorite (Fig. 3C, D). Several mica pieces are parallel to each other, and they cut across quartz aggregates or locate in the edge of aggregates (Fig. 3C, D). Some newly formed micas precipitate in the fractures of plagioclase grains and the grain boundaries of quartz aggregates (Fig. 3D).

The deformed Zone B is the most prominent characteristic of the mylonites with the porphyroclasts (feldspar and hornblende) embedded in a fine-grained matrix (Fig. 3D, E). The feldspar porphyroclasts are smaller in size compared to Zone A, with the features of elongated and lenticular, as well as irregular and serrated grain boundaries. Inhomogeneous extinctions of porphyroclastic feldspar grains are apparent, indicating plastic deformation. The elongated hornblende porphyroclasts form the mineral fish fabrics, presenting a dextral sense of shear (Fig. 3D, G). Locally, the quartz grains form typical polygonal aggregates, with the long axis parallel to or subparallel to the major stretching lineation in the small-scale shear zone. The matrix consists of plagioclase, Kfeldspar, quartz, and biotite, containing a minor content of apatite. The mineral phases in the fine-grained matrix are not homogeneously mixed. Instead, the layering of compositions can be observed (Fig. 3E). Those layered aggregates of minerals exhibit an orientation roughly parallel to the mylonitic foliation.

The BSE images imply that the K-feldspar layers are composed of many small aggregates of fine-grained quartz and plagioclase (Fig. 4D, E). The same situation can be observed in the plagioclase layers (Fig. 4D, F). Additionally, some small grains of mica are distributed in the plagioclase grain boundaries as rod-like cross-sections (Fig. $4 F)$. In contrast to the quartz-rich aggregates in Zone A, the quartz aggregates in Zone B are not bulk but layered (Fig. 3E). The grain boundary of quartz is irregular. Moreover, many relatively small, recrystallized quartz grains are mixed with K-feldspar, plagioclase, and biotite in the matrix at the edge of the aggregates (Fig. 4D). In the quartz-rich layers, isolated $\mathrm{K}$-feldspar grains exist at triple junctions of quartz grains, and some small grains of biotite are distributed in the grain boundary (Fig. 4D). Except for the small grains in the quartz grain boundary, most biotite grains are highly elongated subparallel to the foliation and form biotite-rich layers (Fig. 3G). 
https://doi.org/10.5194/se-2022-2

Preprint. Discussion started: 25 January 2022

(c) Author(s) 2022. CC BY 4.0 License.
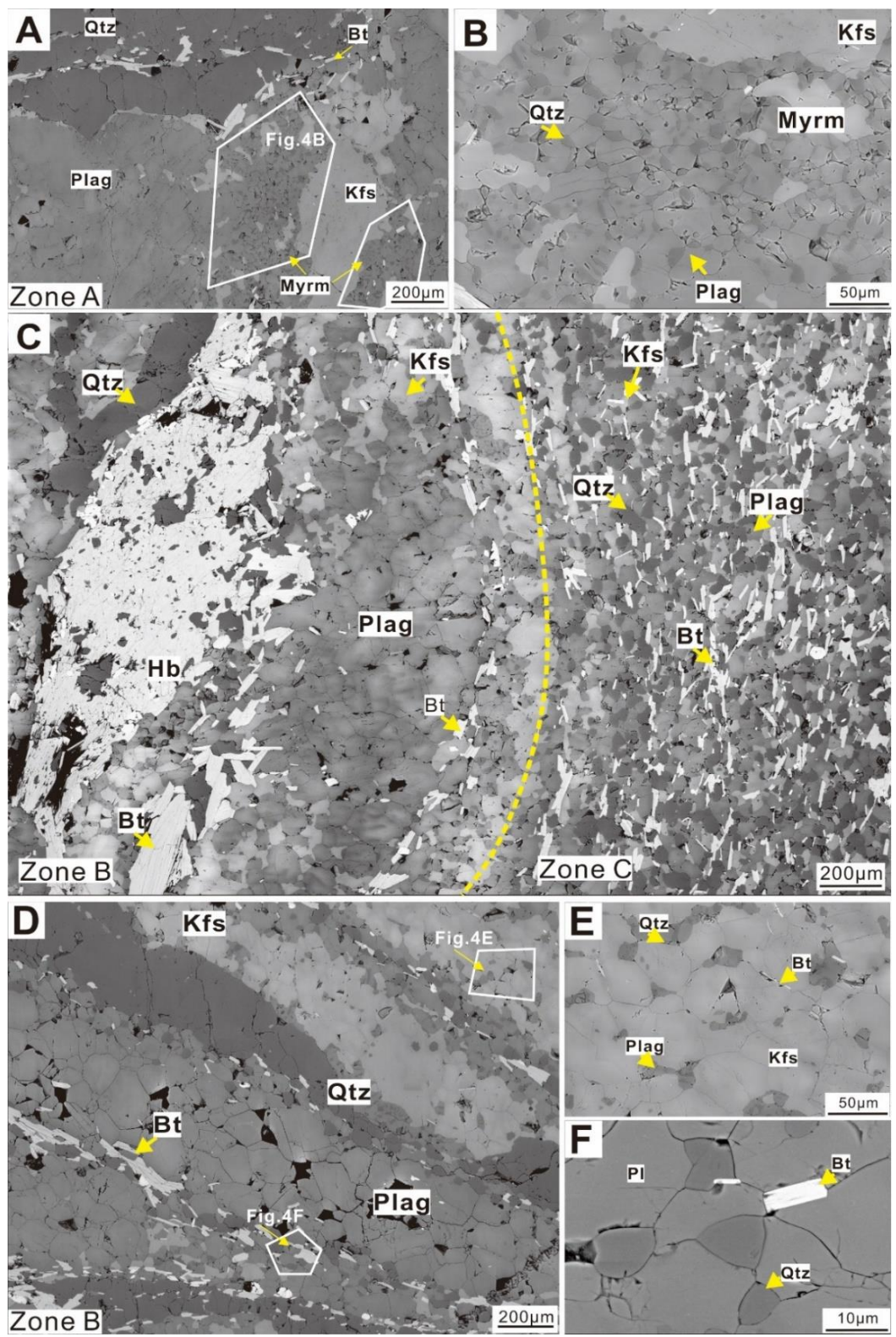

Fig.4. SEM-BSE images of small-scale shear zone. (A)-(B) Quartz and Plagioclase irregular aggregates and the nucleation of fine-grained quartz and plagioclase grains around $K$-feldspar clasts in the Zone A. (C) The transition area from Zone B to Zone C. (D) Fine-grained layers in the Zone B. (E) The nucleation of fine-grained quartz and 306 plagioclase grains in K-feldspar-rich layers in the Zone B. $(F)$ The nucleation of finegrained quartz in plagioclase -rich layers in the Zone $B$. 
Zone $\mathrm{C}$ presents the dominated characteristics of ultramylonites composed of extreme fine-grained matrix and only a few feldspar porphyroclasts with irregular grain boundaries. The hornblende disappears. Zone $\mathrm{C}$ is microstructurally more homogeneous than the other two zones and consists of fine-grained K-feldspar and plagioclase grains (Fig. 3D, F). The fine-grained grains of feldspar, quartz, and mica are slightly elongate or sub-equant. The feldspar porphyroclasts have disappeared. Quartz grains are disseminated throughout the matrix, and the residual quartz-quartz grain boundaries are more straight compared with those in the quartz aggregates in Zone A or Zone B (Fig. 4C). Phase boundaries between quartz and plagioclase or K-feldspar are frequently extensively curved. The biotite grains distribute homogeneously in the matrix and are extremely elongated subparallel to the foliation (Fig. 3F, 4C).

\subsection{Mineral grain sizes of the small-scale shear zone}

The grain size significantly decreases as the strain increases from Zone A to Zone C. The software Image $J$ is adopted to count the size of grains by manual operation.

In Zone A, the quartz grain sizes in the quartz-rich aggregates are counted. The mean and median grain sizes are $186 \mu \mathrm{m}$ and $173 \mu \mathrm{m}$, respectively (Fig. 5B, C). In Zone B, the mean and median grain sizes are $88 \mu \mathrm{m}$ and $80 \mu \mathrm{m}$, respectively (Fig. 5B, C). In the weakly deformed domains (Zone A), a relatively broad distribution of grain size can be observed, while a rather narrow distribution of grain size is observed in Zone B, (Fig. 5C). In Zone A and Zone B, larger grain sizes correspond to the grains without recrystallization or recrystallization relict in the quartz-rich aggregates, and the smaller grain sizes correspond to the small, neocrystallized quartz grains in the quartz-rich aggregates or matrix at the edge of the aggregates. In Zone $\mathrm{C}$, the mean diameter of quartz grains is reduced to $44 \mu \mathrm{m}$, and it has the narrowest distribution among the three zones (Fig. 5B, C).

The distribution of plagioclase grain size has a wide range from 80 to 1000 in Zone A (Fig. 5C). The mean and median values of plagioclase grain size are $225 \mu \mathrm{m}$ and 169 $\mu \mathrm{m}$, respectively (Fig. 5B, C). In the box plot, the outliers represent large feldspar porphyroclasts. Therefore, a considerable amount of plagioclase porphyroclasts occurs in Zone A (Fig. 5C). In Zone B, the plagioclase grain size decreases dramatically. The mean and median values of plagioclase grain size are $103 \mu \mathrm{m}$ and $101 \mu \mathrm{m}$ in Zone B, respectively (Fig. 5B, C). The distribution of plagioclase grain size in Zone B is much narrower than the distribution of plagioclase grain size in Zone A. The outliers in the box plot suggest that the amount of plagioclase porphyroclasts significantly decreases in Zone B (Fig. 5C). In Zone C, the mean and median diameters of plagioclase grains are reduced to $65 \mu \mathrm{m}$ and $63 \mu \mathrm{m}$, respectively. Meanwhile, it has the narrowest distribution in the three zones, and there are hardly any plagioclase porphyroclasts (Fig. 5B, C).

Generally, the feldspar grain size is larger than the quartz grain size in all three 
347 zones. The mean and median values of $\mathrm{K}$-feldspar grain size are $165 \mu \mathrm{m}$ and is $145 \mu \mathrm{m}$ 348 in Zone A, respectively (Fig. 5B, C). The distribution of K-feldspar grain size is similar 349 to the distribution of quartz grain size in Zone A. In Zone B, the mean and median values 350 of K-feldspar grain size are all $97 \mu \mathrm{m}$. The distribution of K-feldspar grain size in Zone $351 \mathrm{~B}$ is narrower than the distribution of $\mathrm{K}$-feldspar grain size in Zone A. The outliers in the 352 box plot reflect that the amount of $\mathrm{K}$-feldspar porphyroclasts significantly decreases in 353 Zone B (Fig. 5B, C). In Zone C, it has the narrowest distribution in the three zones, and 354 there are hardly any K-feldspar porphyroclasts. The mean and median values of K355 feldspar grain size are $60 \mu \mathrm{m}$ and $59 \mu \mathrm{m}$, respectively (Fig. 5B, C). 
https://doi.org/10.5194/se-2022-2

Preprint. Discussion started: 25 January 2022

(c) Author(s) 2022. CC BY 4.0 License.

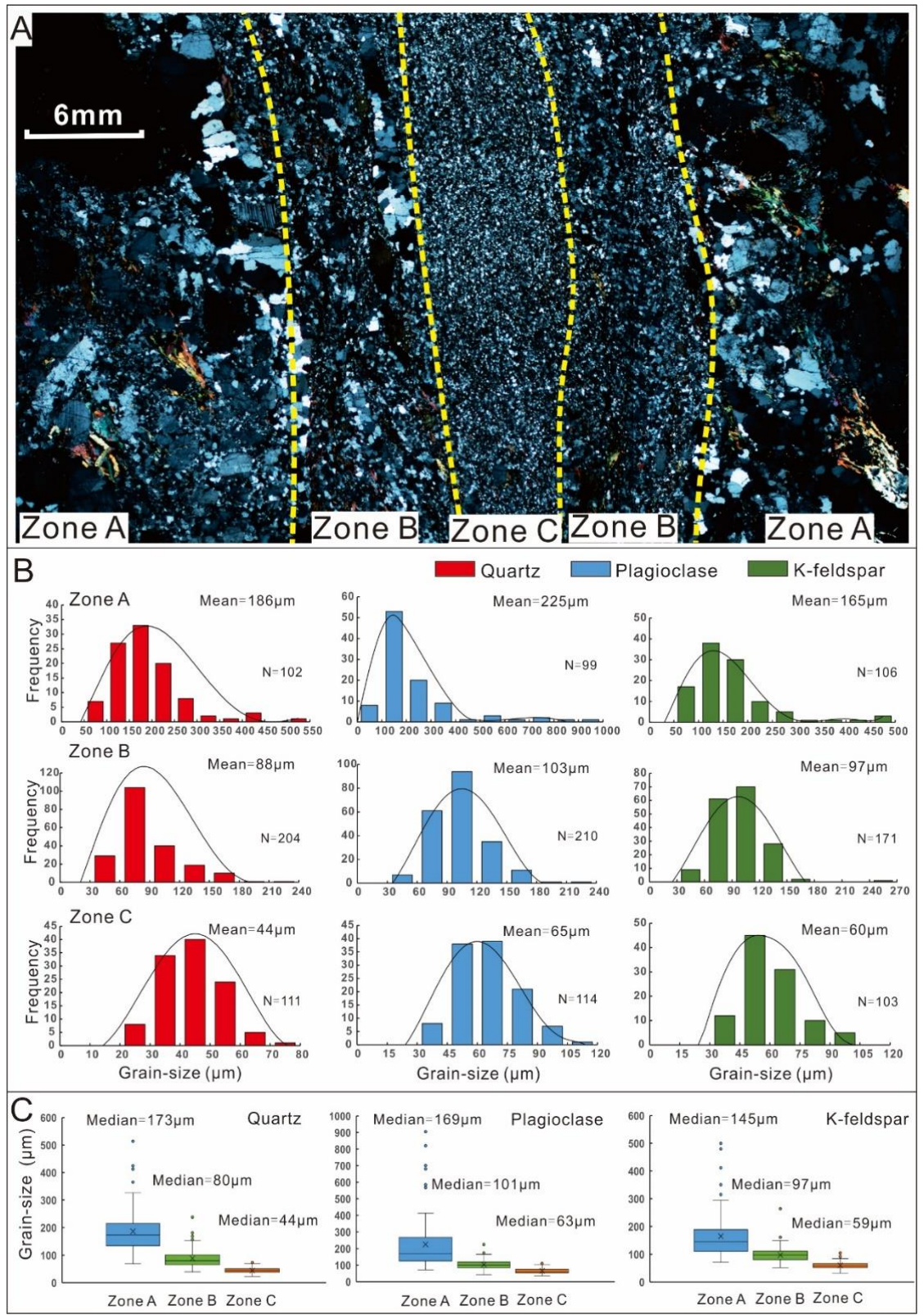

Fig.5. Mineral grain size evolution in the small-scale shear zone. (A) Thin-section scanning of small-scale shear zone. cross-polarized light micrographs. (B) Grain size distribution diagram of minerals in Zone A, B and C of small-scale shear zone. (C) The box-and-whisker diagram illustrates the results. Individual boxes were determined by

361 their upper and lower quartiles, and the median was defined inside them. This 362 progression of grain size is derived from CL pictures. 


\section{Mineral EBSD analysis in the small-scale shear zone}

CPOs of quartz and feldspar were investigated mainly on the three zones (Zones A, $\mathrm{B}$, and $\mathrm{C}$ ) of the micro-shear zone to further constrain the deformation conditions of the small-scale shear zones. The results are illustrated in equal-area lower-hemisphere pole figures.

\subsection{Quartz and feldspar aggregates in the Zone A}

In Zone A, the quartz grains mainly formed irregular polycrystalline aggregates, and Dauphiné twins are occasionally observed in it (Fig. 6A). The pole figure of $\mathrm{c}-<0001>$ axis exhibits a well-developed point maximum near the Y-axis, with a maximum value of multiples of uniform distribution (MUD) of $\sim 6.42$. The pole figures of $\mathrm{m}-(10-10)$ and a-(11-20) planes present a weaker girdle close to the XZ plane (Fig. 6B). In the sample coordinate system (SCS), the low angle $\left(2^{\circ}-15^{\circ}\right.$ in this article) rotation axes demonstrate high spatial density close to the Y-axis, consistent with the pole figure of the c-axis (Fig. 6C). The low angle rotation axes indicate high spatial density close to the c-axis in the crystal coordinate system (CCS; Fig. 6C). In the misorientation angle distribution histogram, the relative frequency of misorientation angles less than $15^{\circ}$ is around 0.08 , and the relative frequency of misorientation angle of $60^{\circ}$ is around 0.13 in the corrected pairs (Fig. 9A). The misorientation angle distribution of the uncorrected pairs exhibits an irrelevance with the calculated random distribution curve (Fig. 9A).

The K-feldspar porphyroclasts gather into aggregates and are surrounded by large quantities of small quartz and plagioclase grains in Zone A (Fig. 6A). The pole figure of $\mathrm{K}$-feldspar reveals a low maximum value of MUD, which is 2.69. The (100) plane forms two maxima in the z-axis, while the pole figures of (010) and (001) planes form a point maximum in the direction with a low angle to the $\mathrm{x}$-axis (Fig. 6B). Although the rotation axes present a point maximum between the $\mathrm{X}$ - and $\mathrm{Z}$-axis in the SCS and a point maximum close to the $<001>$-axis in the CCS, a clear clustering is not observed in the low angle rotation axis distributions of K-feldspar (Fig. 6C). In the misorientation angle distribution histogram, the distribution of misorientation angles of corrected pairs is uniform except $<15^{\circ}$ and $180^{\circ}$, whose relative frequencies are much high than other angles. The misorientation angle distribution of the uncorrected pairs reveals a positive correlation with the calculated random distribution curve (Fig. 9B).

The shape of plagioclase grains is regular, and Albite twins are common in the plagioclase grains in Zone A (Fig. 6A). The pole figure of plagioclase suggests a low maximum value of MUD, which is 2.23 . The plagioclase and K-feldspar have similar crystallographic orientations in the $(001)$ plane. The $(010)$ plane forms a maximum 
between the $\mathrm{X}$ - and Z-axis, and the (100) plane presents high spatial density near the $\mathrm{Y}$ direction (Fig. 6B). In the SCS, the low angle rotation axes demonstrate high spatial density in the position between the $\mathrm{X}$ - and $\mathrm{Z}$-axis, and the low angle rotation axes reflect high spatial density close to the $<100>$-axis in the CCS. The low angle rotation axis distributions of plagioclase are also disorderly similar to K-feldspar's (Fig. 6C). In the misorientation angle distribution histogram, the misorientation angle of $180^{\circ}$ has the highest relative frequency of around 0.15 in the corrected pairs. The misorientation angle distribution of the uncorrected pairs exhibits a positive correlation with the calculated random distribution curve. The difference is that the random distribution curve rises linearly (Fig. 9C).
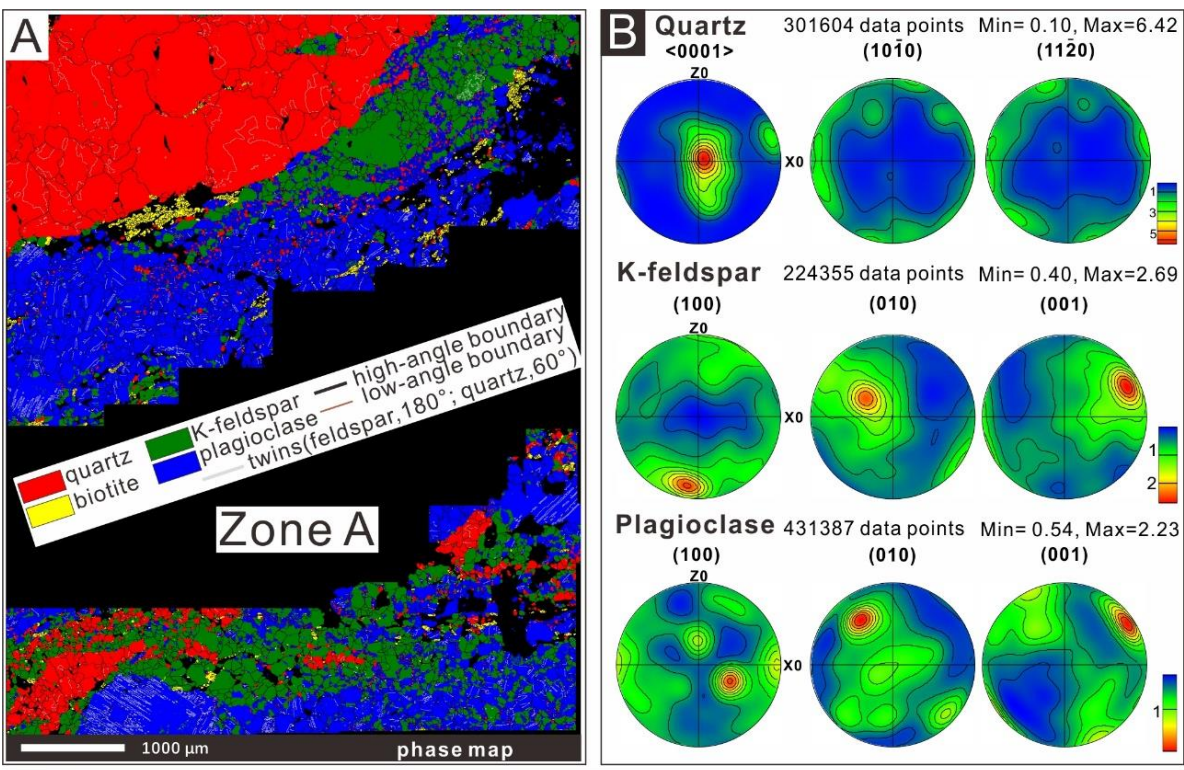

K-feldspar 224355 data points $\operatorname{Min}=0.40, \operatorname{Max}=2.69$ (100)

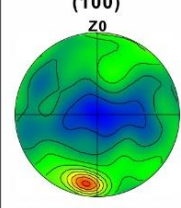
(010) (001)

Plagioclase 431387 data points $\operatorname{Min}=0.54, \operatorname{Max}=2.23$
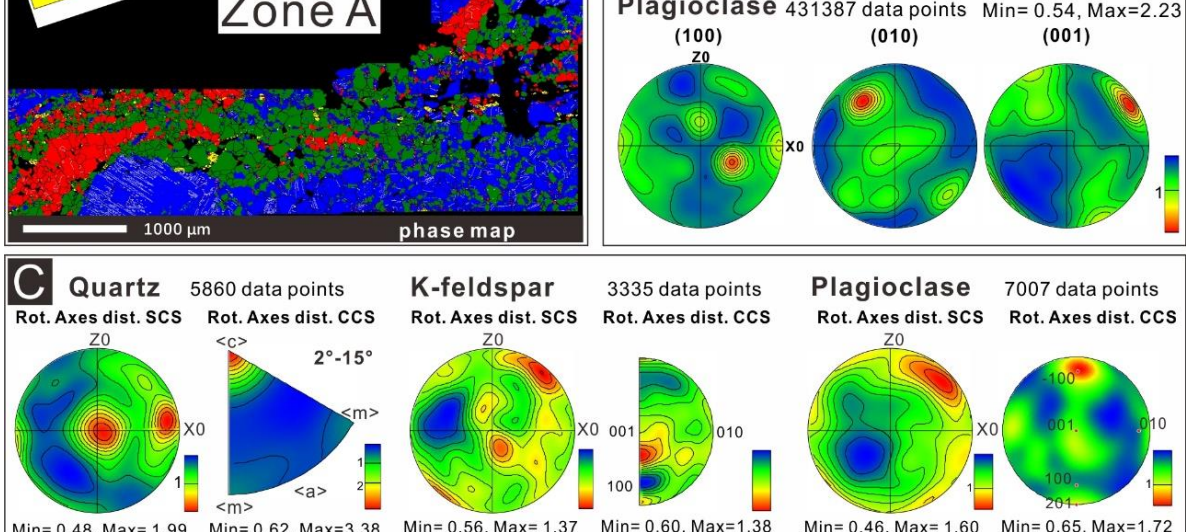

K-feldspar

3335 data points
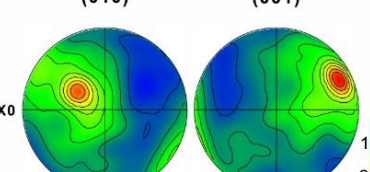


\subsection{Quartz ribbons and feldspar layers in the Zone B}

In Zone B, the quartz irregular polycrystalline aggregates have disintegrated, and the content of quartz in the matrix is higher than those in Zone A (Fig. 7A). The pole figure of the c-axis reveals a well-developed point maximum in the Y-axis, with the maximum value of MUD of $\sim 5.33$. The pole figures of $\mathrm{m}$ - and a-plane show a weaker girdle in the XZ plane (Fig. 7B). In the SCS, the low angle rotation axes suggest high spatial density close to the Y-axis, similar to the pole figure of the c-axis (Fig. $6 \mathrm{H}$ ). The low angle rotation axes exhibit high spatial density close to the c-axis in the CCS (Fig. 7C). In the misorientation angle distribution histogram, the relative frequency of the corrected pairs' misorientation angles $\left(<15^{\circ}\right)$ is also around 0.08 , while the relative frequency of misorientation angles $\left(60^{\circ}\right)$ is around 0.12 , which is less than the value in the Zone A. The misorientation angle distribution of the uncorrected pairs presents a negative correlation with the calculated random distribution curve (Fig. 9A).

In Zone B, the K-feldspar porphyroclasts are hardly observed, and the smaller grains gather into K-feldspar layers (Fig. 7A). The pole figure of K-feldspar reveals a low maximum value of MUD of $\sim 2.14$. The pole figure of the (100) plane forms a point maximum near the $\mathrm{X}$-axis. The pole figures of (010) and (001) planes present weak patterns (Fig. 7B). The low angle rotation distributions indicate very scattered data, and the quantity of data points reduces to $70 \%$ compared to Zone A (Fig. 7C). The distribution of misorientation angles is also in line with those in Zone A, while the relative frequency of $<15^{\circ}$ and $180^{\circ}$ is lower in the corrected pairs. The misorientation angle distribution of the uncorrected pairs exhibits a positive correlation with the calculated random distribution curve (Fig. 9B).

The pole figure of plagioclase reveals a low maximum value of MUD of $\sim 1.90$. The pole figure of the (001) plane forms maxima between the $\mathrm{X}$ - and $\mathrm{Z}$-axis, and the pole figures of (100) and (010) planes present weak patterns (Fig. 7B). The low angle rotation distributions also indicate very scattered data, and the quantity of data points decreases to $40 \%$ compared with that of Zone A (Fig. 7C). The distribution of misorientation angles is consistent with those in Zone A, while the relative frequency of $180^{\circ}$ is lower in the corrected pairs. The misorientation angle distribution of the uncorrected pairs demonstrates a positive correlation with the calculated random distribution curve. Besides, the random distribution curve rises linearly (Fig. 9C). 

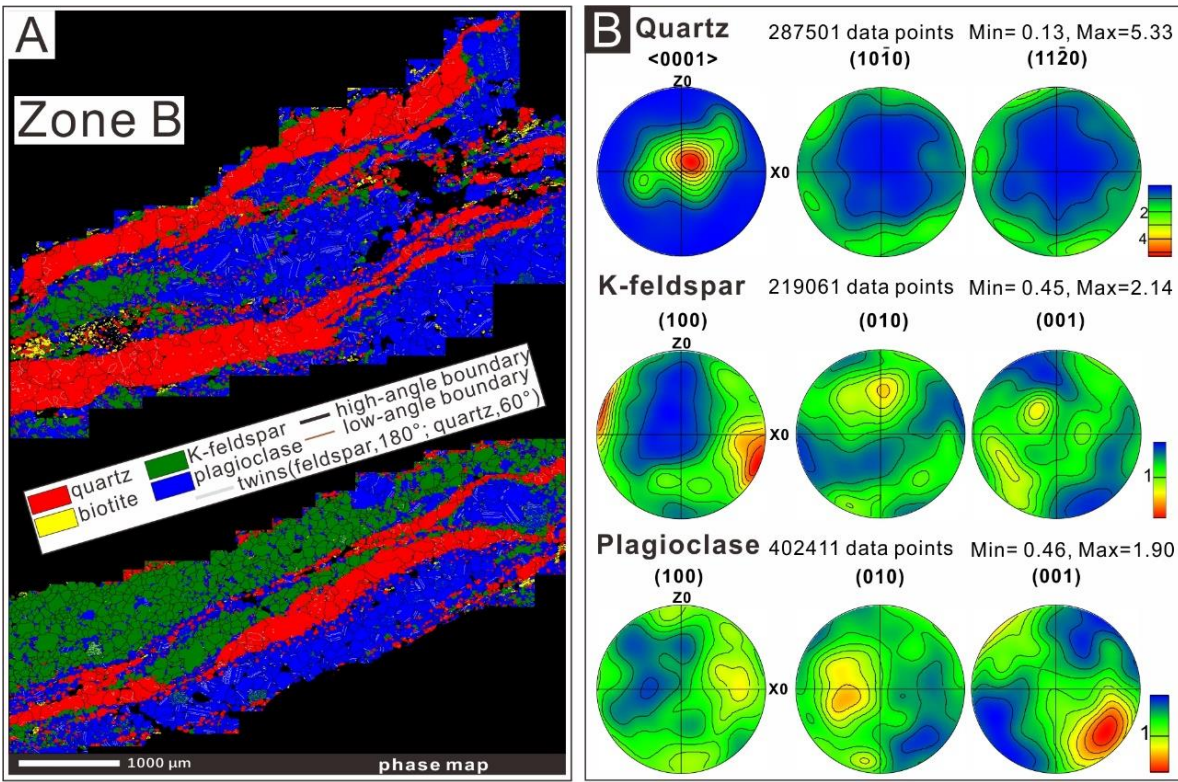

K-feldspar 219061 data points $\operatorname{Min}=0.45$, Max $=2.14$

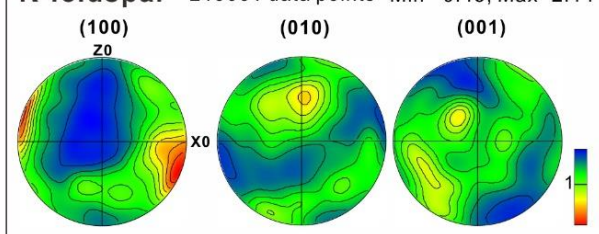

Plagioclase 402411 data points $\operatorname{Min}=0.46, \operatorname{Max}=1.90$

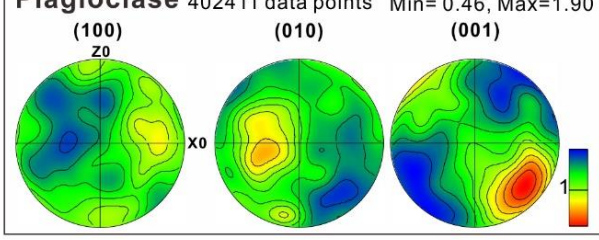

Quartz 7841 data points

K-feldspar

2429 data points

Plagioclase 2866 data points Rot. Axes dist. SCS Rot. Axes dist. CCS

Rot. Axes dist. $S$

Rot. Axes dist. CCS Rot. Axes dist. SCS Rot. Axes dist. CCS

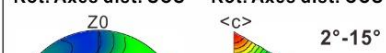

Rot. Axes dist.
Z0
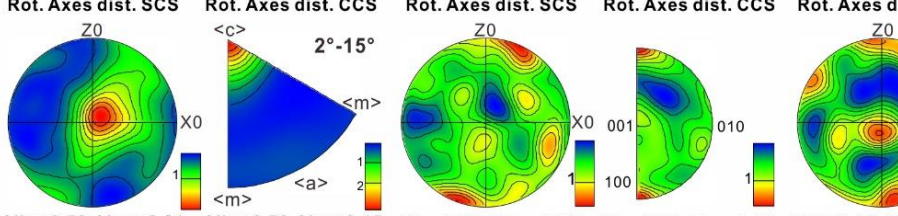

$\operatorname{Min}=0.53, \operatorname{Max}=2.21 \operatorname{Min}=0.70, \operatorname{Max}=3.15 \operatorname{Min}=0.51, \operatorname{Max}=1.57 \operatorname{Min}=0.56, \operatorname{Max}=1.67 \quad \operatorname{Min}=0.67, \operatorname{Max}=1.36 \quad \operatorname{Min}=0.62, \operatorname{Max}=1.49$

Fig. 7. EBSD map and Quartz, K-feldspar and plagioclase crystallographic orientation data in the Zone B. (A) EBSD phase map and grain boundary map. (B) Contoured pole figures of quartz, $K$-feldspar, and plagioclase. (C) Rotation axes of $2^{\circ}-15^{\circ}$ distributions for quartz, K-feldspar, and plagioclase in sample and crystal coordinate system. The pole figures are plotted as one point per pixel. The pole figures and Rotation axes distributions are projected to XZ plane at half width $25^{\circ}$, data clustering $5^{\circ}$. Red color marks maxima, also given as multiples of the uniform distribution.

\subsection{Mixed matrix of quartz and feldspar in the Zone $\mathrm{C}$}

In Zone $\mathrm{C}$, the quartz grains are completely disseminated among the other matrix phases (Fig. 8A). The pole figures suggest a low maximum value of MUD of $\sim 1.50$. A clear clustering is not observed in the pole figure of the c-axis. The pole figures of $\mathrm{m}$ and a-plane present a weak and wide girdle in the XZ plane (Fig. 8B). The low angle rotation axes exhibit a maximum close to the $\mathrm{c}$-axis in the $\mathrm{CCS}$, while it is much weaker compared with Zones A and B (Fig. 8C). In the misorientation angle distribution histogram, the relative frequency of the corrected pairs' misorientation angles $\left(<15^{\circ}\right)$ 
drops to 0.04 , and the relative frequency of misorientation angles $\left(60^{\circ}\right)$ decreases to 0.08 . The misorientation angle distribution of the uncorrected pairs displays a positive correlation with the calculated random distribution curve (Fig. 9A).

The feldspar grains are mixed with quartz grains in Zone C (Fig. 8A). The pole figure of K-feldspar reveals a low maximum value of MUD of $\sim 1.67$ (Fig. $8 \mathrm{~B}$ ). The low angle rotation distributions also suggest very scattered data without a clear clustering (Fig. 8C). In the misorientation angle distribution histogram of corrected pairs, the relative frequency of misorientation angles $\left(180^{\circ}\right)$ is low. The misorientation angle distribution of the uncorrected pairs exhibits a positive correlation with the calculated random distribution curve (Fig. 9B). The pole figure of plagioclase demonstrates a low maximum value of MUD of $\sim 2.37$. The feature of the pole figure of the (001) plane is consistent with that in Zone B (Fig. 8B). However, the low angle rotation distributions reflect few scattered data (Fig. $8 \mathrm{C}$ ). The relative frequency of misorientation angles $\left(180^{\circ}\right)$ is around 0.10 in the misorientation angle distribution of corrected pairs. The uncorrected pairs present a positive correlation with the calculated random distribution curve. Additionally, the random distribution curve also rises linearly (Fig. 9C).

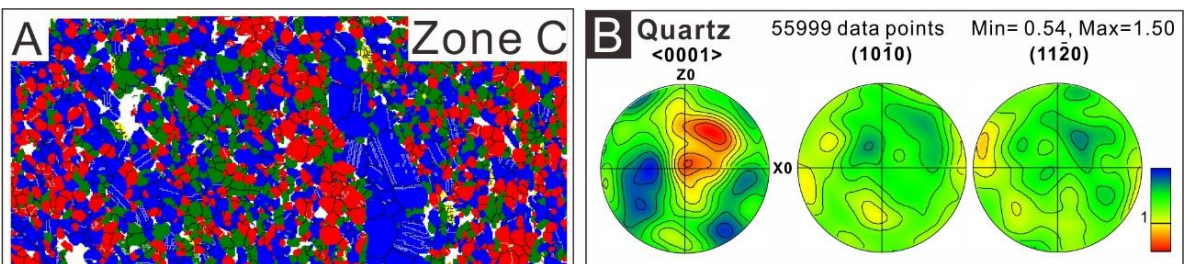

K-feldspar 49722 data points $\operatorname{Min}=0.42, \operatorname{Max}=1.67$
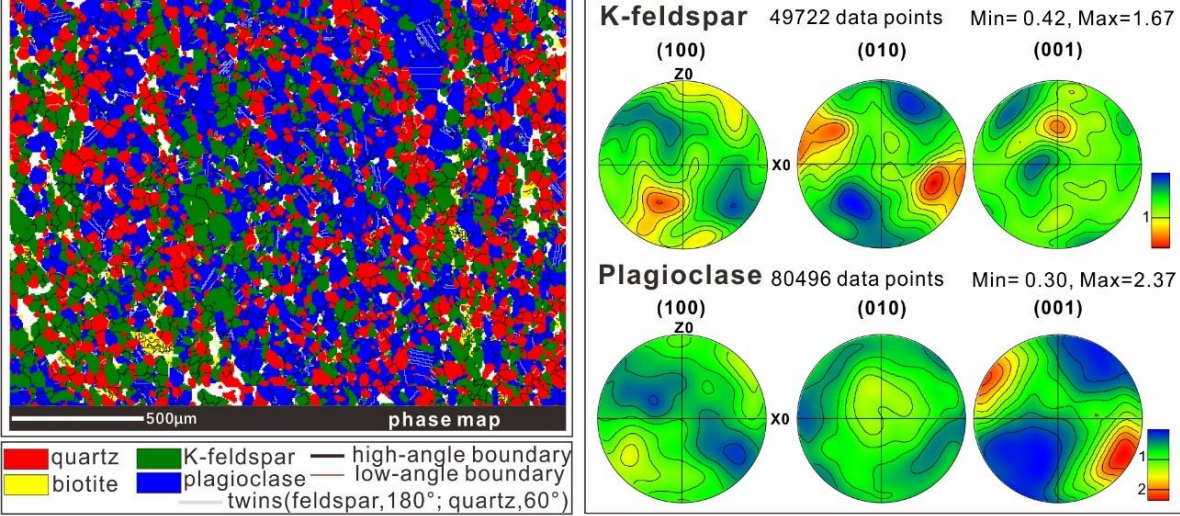

Plagioclase 80496 data points $\operatorname{Min}=0.30, \operatorname{Max}=2.37$

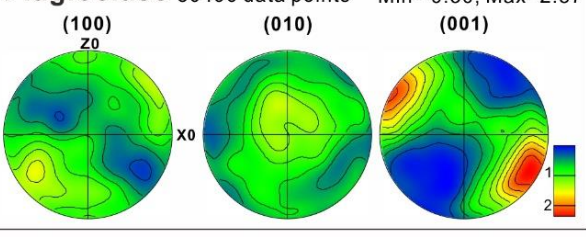
twins(feldspar, $180^{\circ}$; quartz,60

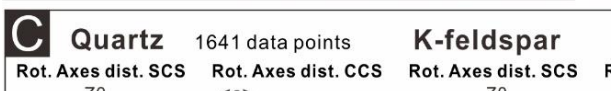

706 data points Plagioclase 453 datapoints Rot. Axes dist. CCS Rot. Axes dist. SCS Rot. Axes dist. CCS
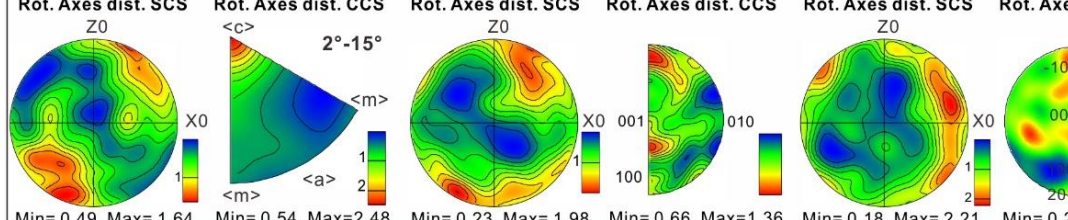

$\operatorname{Min}=0.49, \operatorname{Max}=1.64 \operatorname{Min}=0.54, \operatorname{Max}=2.48 \quad \operatorname{Min}=0.23, \operatorname{Max}=1.98 \quad \operatorname{Min}=0.66, \operatorname{Max}=1.36 \quad \operatorname{Min}=0.18, \operatorname{Max}=2.21 \quad \operatorname{Min}=0.28, \operatorname{Max}=1.77$

Fig. 8. EBSD map and Quartz, K-feldspar and plagioclase crystallographic orientation 
data in the Zone B. (A) EBSD phase map and grain boundary map. (B) Contoured pole figures of quartz, K-feldspar, and plagioclase. (C) Rotation axes of $2^{\circ}-15^{\circ}$ distributions for quartz, K-feldspar, and plagioclase in sample and crystal coordinate system. The pole figures are plotted as one point per pixel. The pole figures and Rotation axes distributions are projected to XZ plane at half width $25^{\circ}$, data clustering $5^{\circ}$. Red color marks maxima, also given as multiples of the uniform distribution.
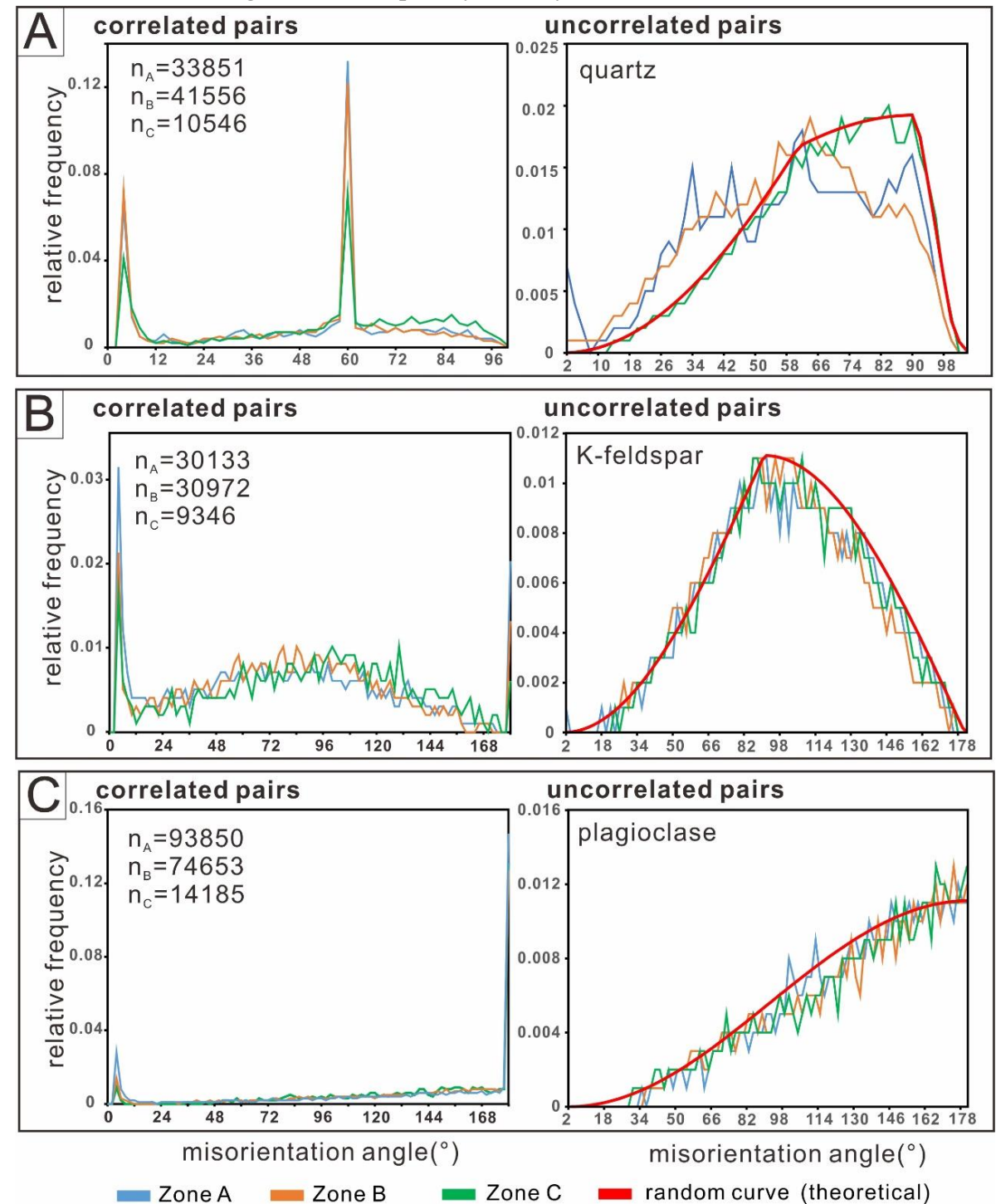

Fig. 9. Misorientation angle distribution for correlated and uncorrelated pairs of Fig.6.

493 (A) quartz, (B) K-feldspar, and (C) plagioclase in the Zone A, Zone B and Zone C. Solid

494 blue lines mark the mineral misorientation angle distribution in Zone A; Solid orange

495 lines mark the mineral misorientation angle distribution in Zone B; Solid green lines 
mark the mineral misorientation angle distribution in Zone C. Solid red line marks the calculated random distribution and the number of statistics is 10000 in the random misorientation. In the correlated misorientation, $n_{A}=$ the number of statistics in Zone A, $n_{B}=$ the number of statistics in Zone B, $n_{C}=$ the number of statistics in Zone $C$.

\section{Thermobarometry of the granodiorite}

\subsection{P-T estimation}

Hornblende-plagioclase thermometry is frequently utilized in granites and gneisses with coexisting hornblende and plagioclase to estimate temperature and pressure in magma crystallization or subsequent metamorphism (Schmidt, 1992; Popp et al., 1995; Ridolfi and Renzulli, 2011; Dong et al., 2021). Mineral chemistry was determined on unfoliated granodiorite at the GLG-SZ boundary and on foliated granitic rocks within the GLG-SZ. Experiments were conducted on hornblende grains combined with quartz or plagioclase under the premises for Al-in-hornblende barometry application (Hollister et al., 1987; Schmidt, 1992; Popp et al., 1995; Stein and Dietl, 2001; Ridolfi and Renzulli, 2011). In this study, the hornblende-plagioclase geothermometer designed by Holland and Blundy (1994) is employed to determine the temperature. These calculations were based on hornblende solid-solution models and well-constrained natural systems. The temperatures and pressures of the unfoliated granitoids are $\mathrm{T}=641-730{ }^{\circ} \mathrm{C}$ with an average of $\mathrm{T}=673{ }^{\circ} \mathrm{C}, \mathrm{P}=4.0-5.9 \mathrm{kbar}$ with an average of $\mathrm{P}=5.1 \mathrm{kbar}$ (Fig. 10A). The crystallization P-T values for the foliated granitic rocks are $\mathrm{T}=658-736{ }^{\circ} \mathrm{C}$ with an average of $\mathrm{T}=710^{\circ} \mathrm{C}, \mathrm{P}=2.1-2.9 \mathrm{kbar}$ with an average of $\mathrm{P}=2.7 \mathrm{kbar}$ (Fig. 10B)

\subsection{Emplacement depth}

The crystallization pressures for the investigated granodiorite are calculated by the method developed by Anderson and Smith (1995). It is possible to estimate the pressure with an error of about 0.6 kbar using the method proposed by Popp et al. (1995). This error corresponds to about $2.10 \mathrm{~km}$ in depth. The density assumption of $2.8 \mathrm{~g} / \mathrm{cm}^{3}$ is used for the GLG-SZ in our calculations to convert the pressures measured to emplacement depths. After the temperature adjustment, the calculated unfoliated granitoids' pressures range from $4.0 \pm 0.6 \mathrm{kbar}$ to $5.8 \pm 0.6 \mathrm{kbar}$, implying that emplacement depths range from $14.3 \pm 2.1 \mathrm{~km}$ to $20.7 \pm 2.1 \mathrm{~km}$, and the average depth is $17.5 \mathrm{~km}$ (Fig. 10A). The calculated pressures in the foliated granitic samples change from $2.2 \pm 0.6 \mathrm{kbar}$ to $2.9 \pm$ $0.6 \mathrm{kbar}$, suggesting that emplacement depths vary from $7.8 \pm 2.1 \mathrm{~km}$ to $10.3 \pm 2.1 \mathrm{~km}$, and the average depth is $9.0 \mathrm{~km}$ (Fig. 10B). 

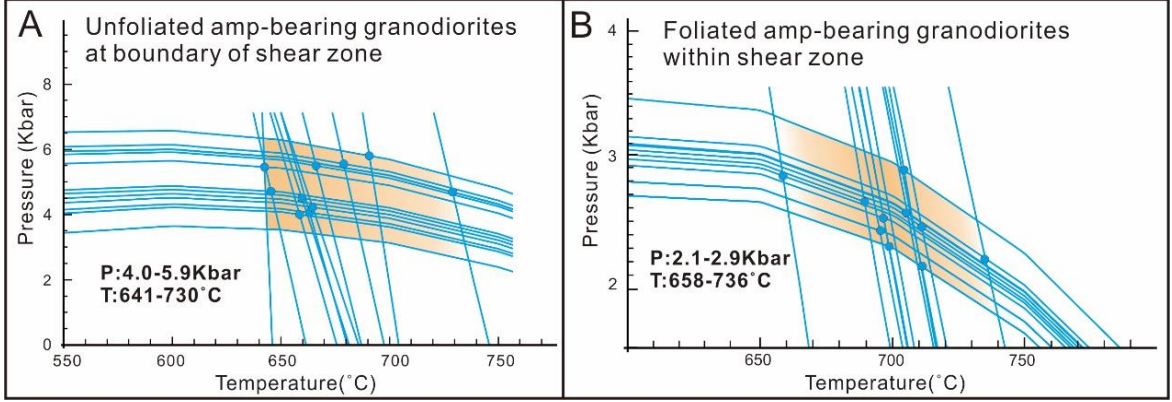

Fig. 10. Pressure-temperature diagram of unfoliated granitoids at boundary of GLG-SZ and foliated granitic rocks within GLG-SZ.

\section{Paleopiezometry}

\subsection{Flow stress estimate from recrystallized quartz grains}

The grain size of dynamically recrystallized quartz varies with differential stress in plastic deformation and is used as a method for calibrating the magnitude of paleostress (Mercier et al., 1977; Twiss, 1977; Twiss, 1980; Koch, 1983; Boutonnet et al., 2013). This study only considered dynamically recrystallized quartz grain sizes from the smallscale shear zones for estimating paleostress. The optical size of recrystallized grains was determined with standard petrographic microscopy. Measurements were performed with each grain perpendicular to macroscopic foliation and parallel to macroscopic lineation (Behrmann and Seckel, 2007). The results of the analysis are listed in Table 1. The standard error of the differential stress estimates is less than $15 \%$.

The differential stress is estimated through piezometer calibration (Stipp and Tullis, 2003), followed by a calibration corrected by Holyoke and Kronenberg (2010). The lowstrain domain (Zone A) average size is $165 \mu \mathrm{m}$; the differential flow stress is $12 \mathrm{MPa}$ (Stipp and Tullis, 2003) and $9 \mathrm{MPa}$ (Holyoke and Kronenberg, 2010). The medium-strain domain (Zone B) average size is $78 \mu \mathrm{m}$; the differential flow stress is $21 \mathrm{MPa}$ (Stipp and Tullis, 2003) and $15 \mathrm{MPa}$ (Holyoke and Kronenberg, 2010). The high-strain domain (Zone C) average size is $44 \mu \mathrm{m}$; the differential flow stress is $33 \mathrm{MPa}$ (Stipp and Tullis, 2003 ) and $24 \mathrm{MPa}$ (Holyoke and Kronenberg, 2010). However, uncertainties remain in the estimation of flow stress from the mineral grain sizes that can be affected by the presence of other phases and notably fluid during deformation.

\subsection{Flow stress estimate from recrystallized grain size}

Estimating the strain rate is a critical step in comprehending deformation processes. The relationships between temperature, microstructures, and $\mathrm{CPO}$ patterns corresponding to the dominant slip systems indicate deformation under amphibolite- 
559 facies conditions at temperatures of ca. $400{ }^{\circ} \mathrm{C}-700{ }^{\circ} \mathrm{C}$ in the small-scale shear zones 560 (Hirth and Tullis, 1992; Stipp et al., 2002). In this study, strain rates of quartz grains at 561 temperatures of ca. $550^{\circ} \mathrm{C}$ were constructed. Ductile creep curves were calculated for 562 strain rates from $10^{-10}$ to $10^{-16} \mathrm{~S}^{-1}$ following the flow law from Luan and Peterson (1992)

563 and the wet quartzite flow law of Hirth et al. (2001). In the calculation, the effect of water 564 fugacity was considered, though the dependence of strain rate on water fugacity was not 565 determined in the original paper. When it was applied to the differential stress estimates 566 from dynamically recrystallized grain sizes of quartz by the piezometer (Stipp and Tullis, 567 2003; Holyoke and Kronenberg, 2010), strain rates estimated in Zone A are $4.75 \times 10^{-16}$ $568 \mathrm{~S}^{-1}$ to $1.17 \times 10^{-14} \mathrm{~S}^{-1}$, strain rates estimated in Zone $\mathrm{B}$ are $5.13 \times 10^{-15} \mathrm{~S}^{-1}$ to $1.26 \times 10^{-}$

$569{ }^{13} \mathrm{~S}^{-1}$, and strain rates estimated in Zone $\mathrm{C}$ are $3.16 \times 10^{-14} \mathrm{~S}^{-1}$ to $7.75 \times 10^{-13} \mathrm{~S}^{-1}$. The 570 average strain rate estimated in Zone $A$ is $4.29 \times 10^{-15} \mathrm{~S}^{-1}$, the average strain rate 571 estimated in Zone B is $4.62 \times 10^{-14} \mathrm{~S}^{-1}$, and the average strain rate estimated in Zone C 572 is $2.85 \times 10^{-13} \mathrm{~S}^{-1}$.

573 Table 1

574 Paleopiezometry data for quartz and deduced strain rates in the small-scale shear zone. 575

\begin{tabular}{|c|c|c|c|c|c|c|c|}
\hline Domain & $\begin{array}{l}\text { Recrystall. } \\
\text { regime }\end{array}$ & $\begin{array}{l}\text { Apparent grainsize } \\
\text { (microns) }\end{array}$ & $\begin{array}{c}\text { Paleopiez- } \\
\text { ometer }\end{array}$ & $\begin{array}{l}\text { Stress } \\
(\mathrm{MPa})\end{array}$ & $\mathrm{T}\left({ }^{\circ} \mathrm{C}\right)$ & Flow law & Strain rate $(1 / \mathrm{s})$ \\
\hline \multirow{2}{*}{ Zone A } & \multirow{2}{*}{ GBM } & \multirow{2}{*}{165} & ST-2003 & 12 & 550 & $\begin{array}{r}\text { H-2001 } \\
\text { LP-1992 }\end{array}$ & $\begin{array}{l}1.17 \mathrm{E}-14 \\
1.67 \mathrm{E}-15\end{array}$ \\
\hline & & & SH-2010 & 9 & 550 & $\begin{array}{r}\text { H-2001 } \\
\text { LP-1992 }\end{array}$ & $\begin{array}{l}3.33 \mathrm{E}-15 \\
4.75 \mathrm{E}-16\end{array}$ \\
\hline \multirow{2}{*}{ Zone B } & \multirow{2}{*}{ GBM+GBS } & \multirow{2}{*}{78} & ST-2003 & 21 & 550 & $\begin{array}{c}\text { H-2001 } \\
\text { LP-1992 }\end{array}$ & $\begin{array}{l}1.26 \mathrm{E}-13 \\
1.80 \mathrm{E}-14 \\
\end{array}$ \\
\hline & & & SH-2010 & 15 & 550 & $\begin{array}{c}\text { H-2001 } \\
\text { LP-1992 }\end{array}$ & $\begin{array}{l}3.59 \mathrm{E}-14 \\
5.13 \mathrm{E}-15\end{array}$ \\
\hline \multirow{2}{*}{ Zone C } & \multirow{2}{*}{ GBM+GBS } & \multirow{2}{*}{44} & ST-2003 & 33 & 550 & $\begin{array}{c}\text { H-2001 } \\
\text { LP-1992 }\end{array}$ & $\begin{array}{l}7.75 \mathrm{E}-13 \\
1.11 \mathrm{E}-13\end{array}$ \\
\hline & & & SH-2010 & 24 & 550 & $\begin{array}{c}\text { H-2001 } \\
\text { LP-1992 }\end{array}$ & $\begin{array}{l}2.21 \mathrm{E}-13 \\
3.16 \mathrm{E}-14\end{array}$ \\
\hline
\end{tabular}

$576 \quad$ Stress estimated using differential piezometer, ST-2003-Stipp and Tullis, 2003

577 and SH-2010-Koch, 1983. H-2001 flow law is referenced to Hirth et al., 2001, LP-

5781992 flow law is referenced to Luan and Peterson, 1992.

\section{Discussions}

581

\subsection{Significance of quartz CPOs within the small-scale shear zone}

Before this study, the detailed characteristics and conditions of deformation and CPOs of minerals (quartz and feldspar) in the small-scale shear zone were largely 
undocumented and discussed, though numerous data on structures, microfabrics, and geochronology have been published from the GLG-SZ show Cenozoic high-temperature ductile deformation conditions (Zhang et al., 2012b; Xu et al., 2015; Dong et al., 2019). The small-scale shear zone developing in the unfoliated granodiorite presents a significant decrease in grain size from the rim (Zone A) to center (Zone C) with increasing strain. In the low-strain domains of Zones A and B, the quartz polycrystalline aggregated ribbons are characterized by grain boundary migration recrystallization (GMR), revealing a medium-high temperature plastic-deformation condition (Fig.3,6 and 7; Hippertt et al., 2001; Stipp et al., 2002; Passchier and Trouw, 2005; Holyoke and Tullis, 2006; Hansen et al., 2013; Cavalcante et al., 2018; Dong et al., 2019).

The deformation conditions can be recorded by developed dominated slip systems of deformed quartz grains, which are normally temperature-sensitive (Stipp et al., 2002). Prism $<$ a $>$ slip occurs frequently in high-grade metamorphic rocks (Cao et al., 2011b, 2013a, b), while basal $<\mathrm{a}>$ slip appears in low-grade or overprinted metamorphic rocks (Toy et al., 2008; Cao et al., 2010, 2011b; Cheng et al., 2018). The low angle rotation axis distribution and the $\mathrm{C}$-axis patterns of quartz grains from the three zones in the small-scale shear zone display dominated the high-temperature prism $<\mathrm{a}>$ slip system (Fig. 6, 7). However, the quartz c-axis patterns in Zones A and B are more intensive, with the Max between 5.33 and 6.42. The misorientation angle distribution of uncorrelated grain pairs does not conform to the random curve (Fig. 7A).

All these results suggest that the quartz grains in the small-scale shear zone have undergone significant high temperature $\left(>400-700^{\circ} \mathrm{C}\right)$ dislocation creep deformation, similar to the GLG-SZ (Dong et al., 2019). However, the quartz c-axes pattern in Zone $\mathrm{C}$ demonstrates the weaker intensive of 1.50 (Fig. 8B). The effects of intragranular deformation are dramatically reduced (Fig. 9A). Certain minerals from the high-strain zone $\mathrm{C}$ are completely transformed into ultramylonites generated by extremely fine grains. Ultra-plastic flow is an essential process of quartz deformation in the high-strain domain within the shear zone.

\subsection{Mechanism of feldspar deformation and changed CPO patterns}

Studies have demonstrated that feldspars have different deformation behaviors and mechanisms, including brittle fracturing and cataclastic flow in the shallow crustal low-temperature conditions and dynamic recrystallization associated grain-size reduction under the high-temperature conditions (Olsen and Kohlstedt, 1984; Olsen and Kohlstedt, 1985; Tullis and Yund, 1987, 1991; Wintscha and Yi, 2002; Mancktelow and Pennacchioni, 2004; Dang et al., 2017; Menegon et al., 2017; Mansard et al., 2018; Dong et al., 2019). In the studied small-scale shear zone, the feldspar grains present the wellmarked variation of compositions and grain sizes from the undeformed magmatic texture to typical crystal plastic flow deformation, revealed by the microstructure, CL, and CPO 
properties (Fig. 3). In the low-strain domain of Zone A, undulatory and inhomogeneous extinction are common in the porphyroclastic feldspar grains. Occasionally, the feldspar grains exhibit irregular and sharpened grain boundaries. Most K-feldspar porphyroclasts display elongation and grain-size reduction by dynamic recrystallization. The dynamic recrystallization grains occur in the asymmetric porphyroclast (e.g., hornblende and feldspar) tails with neocrystallization aggerates, which extend to the shear zone's mylonitic foliation/lineation. The K-feldspar porphyroclasts are surrounded by quartz, plagioclase, or K-feldspar fine grains, establishing a typical core-mantle structure (Fig. $4 \mathrm{~A}, \mathrm{~B})$. With an increase in the strain, the feldspar porphyroclasts disintegrate, and the fine feldspar grains gather to layered aggregates with an orientation nearly parallel to the mylonitic foliation (Fig. 4E). Fractures or mechanical twins can be observed in a small amount of large K-feldspar porphyroclasts (Fig. 3D).

Under medium-high temperature deformed conditions, the deformation mechanism of K-feldspar is mainly attributed to activation slip systems of $(010)<101>$ or $<100>$ (Tullis,1983; Gandais and Willaime, 1984; Franěk et al., 2006; Ishii et al., 2007; Menegon et al., 2008). Besides, (100) $<010>$ slip occurs in K-feldspar zones under upper greenschist facies condition (Ishii et al., 2007). However, plagioclase often reflects main slip systems of $(010)<001>$ and $(001)<110>$, while $(001)<100>,(010)<100>$, and (111) $<110>$ slips develop slip at higher metamorphic conditions (Svava et al., 1985; Kruhl et al., 1987; Ji et al., 1988; Mainprice et al., 1989; Heidelbach et al., 2000; Kruse et al., 2001; Egydio-Silva et al., 2002; Stünitz et al., 2003; Passchier and Trouw, 2005). Under higher-grade metamorphic conditions or intense grain-size reduction and phrase mixing, diffusion creep is a more critical deformation mechanism (Gower and Simpson, 1992; Menegon et al., 2008, 2013; Czaplińska et al., 2015; Miranda et al., 2016; Dong et al., 2019). In the low-strain domain (Zone A), the EBSD analysis suggests that the dominant slip system in K-feldspar is $(100)<010>$, and the dominant slip system in plagioclase is $(010)<001>$ (Fig.6B, C). The high proportion of low-angle misorientation angles of plagioclase and $\mathrm{K}$-feldspar demonstrates the development of intragranular deformation (Fig.9B, C). Thus, the dislocation creep is the dominant mechanism in feldspar deformation within the low-strain domain (Altenberger and Wilhelm, 2000; Menegon et al., 2017). However, the random distribution of feldspar grains cannot be explained by dislocation creep and the formation of myrmekites induced by dynamic recrystallization. These features imply another mechanism during the feldspar deformation in the lowstrain domain. They are formed by dissolution-precipitation creep (Menegon et al., 2008; Dong et al., 2019) for the result of grain-boundary diffusion (Ishii et al., 2007).

In the high-strain domain (Zone $\mathrm{C}$ ), intense grain-size reduction of minerals generated ultramylonites with the increasing strain. Ultra-plastic flow is a crucial process of deformation in the high-strain domain within the shear zone. The fine-grained feldspar 

(3) rare low-angle grain boundaries (Fig. 8C, 9); (4) uncorrelated misorientation angle distributions close to the theoretical random-pair distribution (Fig. 9). This alignment of grains parallel to the displacement direction is frequently reported in materials deforming with a contribution of grain boundary sliding (GBS; e.g., Drury and Humphreys, 1988; Stünitz and J.D., 1993; Fliervoet et al., 1997; Kilian et al., 2011; Mansard et al., 2018). The weakening of CPOs, phase mixing, and grain size reduction suggest that grain boundary sliding (GBS) becomes increasingly active and an essential deformation mechanism (Passchier and Trouw, 2005; Langdon, 2006; Fusseis et al., 2009; Kilian et al., 2011; Platt, 2015; Miranda et al., 2016; Mansard et al., 2018).

\subsection{Deformation associated fluid of the small-scale shear zone}

671

Recognizing the evolution of small-scale ductile shear zone is also particularly valuable for the understanding of the processes of shear localization in the middle and lower crusts (Mancktelow and Pennacchioni, 2005, 2013; Pennacchioni, 2005; Kilian et al., 2011; Pennacchioni and Mancktelow, 2018), as well as interpreting shear zone history regarding P-T-fluid evolution along strain gradients (Bestmann and Pennacchioni, 2015; Cao and Neubauer, 2016). Hydrolytic weakening has been demonstrated to be a major process facilitating strain localization (Finch et al., 2016; Cao et al., 2017). Fluid can weaken rocks or minerals in several methods (Sibson, 1977; Mancktelow and Pennacchioni, 2004; Kohlstedt, 2006; Kilian et al., 2011; Oliot et al., 2014; Finch et al., 2016; Cao et al., 2017; Cheng et al., 2018). This is in that the fluid in crystals can weaken the mechanical strength of crystals by decreasing the strength of $\mathrm{Si}-\mathrm{O}$ bonds. It allows easier glide of dislocations (Kohlstedt, 2006) and diffusion at lower temperatures (Sibson, 1977). Intergranular fluid results in nucleation of new grains in cavities by mass transfer, contributing to accelerating grain boundary sliding (GBS) and reducing the intercrystalline rock strength (Chen and Argon, 1979; Kronenberg, 1994; Mancktelow and Pennacchioni, 2004; Kilian et al., 2011). The relevant evidence from low-strain (Zone A) or medium-strain domains (Zone B) reveals that quartz and mica grains of extremely small size (ca. $20 \mu \mathrm{m})$ occur at the fine-grained plagioclase aggregates or at the junctions of K-feldspar grains (Fig. 11). This kind of feature can be explained by fluid-accommodated grain boundary sliding (GBS). The incomplete displacement along grain boundaries by GBS can trigger the opening of the cavities and leads to the ingress and diffusion of the material (Fliervoet et al., 1997; Passchier and Trouw, 2005; Kilian et al., 2011; Platt, 2015; Finch et al., 2016; Menegon et al., 2017; Precigout et al., 2017; Mansard et al., 2018). The neocrystallization grains pin in cavities restrains grain growth by impeding grain boundary migration and arresting the original grain size at the approximate size of the dynamic recrystallization new grains. The grain size reduction and the increase of phase mixing can further 
weaken rock and strain localization in the small-scale shear zones.

Intergranular fluid also reduces the intercrystalline rock strength by metamorphic reaction (White and Knipe, 1978; Hippertt, 1998; Oliot et al., 2014; Spruzeniece and Piazolo, 2015; Liu, 2017). For example, the retrogressive metamorphism of hornblende and involved water can produce the weaker phase as biotite and quartz (Fig.4C; Liu, 2017). The studied small-scale shear zones reveal the distinct evidence of strain localization accompanied by hydrous retrogression of hornblende to interconnected weaker mica parallel to the main ultramylonitic foliation. That mica presents the visible appearance from undeformed magmatic phases to ductile deformed phases. The biotite occurs as undeformed or slightly bent magmatic phases in the studied unfoliated granodiorite (Fig. 3), generally regarded as the weakest phase (Tullis and Wenk, 1994). As the strain increases, the micas in the low-strain domain break into small pieces, and several mica pieces are parallel to each other which cut across quartz-rich layers. With further localization, a network of monophase biotite layers starts to form in the mediumstrain domain of Zone B (Fig. 3G). The interconnected mica layers can be frequently formed during crystal plastic deformation. Additionally, a portion of biotite appears at the quartz and plagioclase grain boundaries (Fig. 4). In the high-strain domain, the network of micas is destroyed, and the mica grains are disseminated in the matrix (Fig. $4 \mathrm{C}, 11 \mathrm{C}$ ). This presents similar distributed features to diffusion creep (Fliervoet et al., 1997; Herwegh and Jenni, 2001). The microstructure characteristics imply that the formation of biotite can soften the rock's matrix, resulting in increased deformation intensity (Mancktelow, 2008; Fossen and Cavalcante, 2017; Mansard et al., 2018).
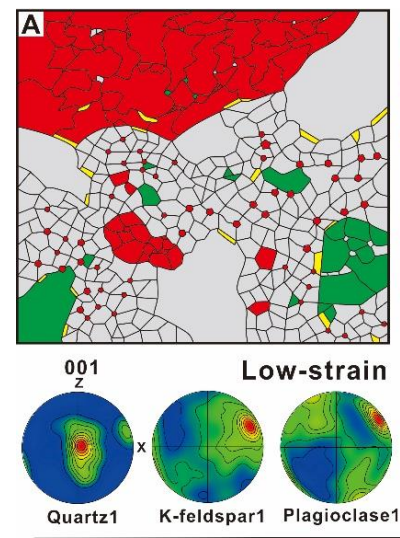
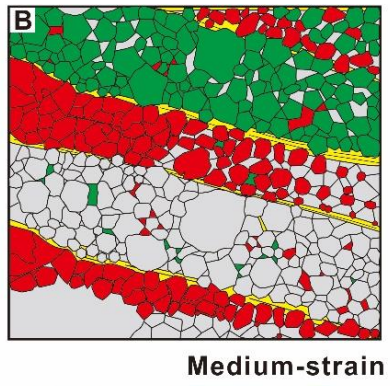
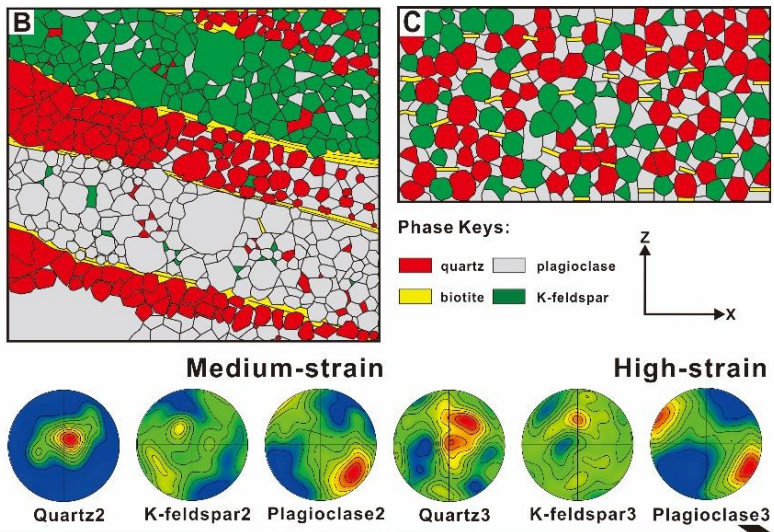

High-strain

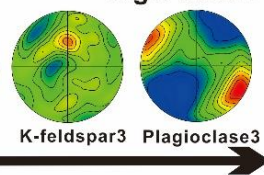

increasing strain

Fig. 11. Representative maps of the different strain domain that have been manually digitized and the variety of mineral c-axis orientation in the small-scale shear zone (A) Low-strain domain which is closed with wall-rock. (B) Medium-strain domain which is strip in shape. (C) High-strain domain which is mixed-phase zone. 


\subsection{Formation conditions and processes of the small-scale shear zone}

Microstructural analyses of the small-scale shear zones reveal ductile deformation processes in the deep-seated crust. The unfoliated granitoids have an average emplacement depth of $18 \mathrm{~km}$. Macro- and micro-structures apparently reveal progressive plastic deformation behaviors of the major mineral phases (quartz, feldspar, hornblende, and mica) in response to a progressive ductile deformation history of the small-scale shear zone (Fig. 11). The results demonstrate that the small-scale shear zone has experienced high-temperature deformation conditions at least amphibolite facies during the dominant ductile shearing. The small-scale shear zones and the foliated granodiorite within the GLG-SZ exhibit identical synkinematic metamorphic assemblages and microstructures (Fig.3; Dong et al., 2019, 2021). In other words, they formed under similar metamorphic and deformation conditions. The temperature conditions of foliated granodiorite are determined based on hornblende-plagioclase thermometry to be 670 $735^{\circ} \mathrm{C}$ (Fig. 10B). Similar temperature conditions are inferred in the small-scale shear zones. The development of myrmekite and the recrystallization of quartz also can verify the high-temperature metamorphic conditions in the small-scale shear zones (Figa.3\&4; Wirth and Voll, 1987; Tribe and D'Lemos, 1996; Ceccato et al., 2018). The initiation of prism $<\mathrm{a}>$ slip and the features of grain boundary migration recrystallization of quartz grains confirm that the small-scale shear zones formed at the medium-high temperature condition (Fig.6; Hobbs, 1985; Mainprice et al., 1986; Stipp and Tullis, 2003; Passchier and Trouw, 2005; Toy et al., 2008; Gibert and Mainprice, 2009; Xia and Liu, 2011).

Generally, rheological weakening mechanisms play a significant role in the localization of shear zones, as shear zones typically form in the weakest zone (Schmid et al., 1996; Imber et al., 1997; Rosenberg, 2004; Dayem et al., 2009; Yamasaki et al., 2014; Cao and Neubauer, 2016; Fossen and Cavalcante, 2017; Liu, 2017; Pennacchioni and Mancktelow, 2018). Besides temperature and pressure, several other factors such as mineralogy, strain rate, microstructure, texture, and fluid that can weaken mechanisms are activated during strain localization (Mancktelow and Pennacchioni, 2004; Oliot et al., 2014; Cao and Neubauer, 2016; Finch et al., 2016; Fossen and Cavalcante, 2017; Liu, 2017; Pennacchioni and Mancktelow, 2018). Localization may be caused by an external inhomogeneity such as a precursor fracture or joint, according to the macroscopic shear zone distribution and orientation similar to joint orientations in the same rock (Menegon and Pennacchioni, 2009). In this study, microstructural observations imply that the switch of deformation characteristics from wall rocks to the high-strain domain cannot be explained by the "precursor effect" (Fig. 3D). This inference cannot be confirmed by the varying orientation of small-scale shear zones (Fig. 1C). The high-temperature deformation conditions suggest that the initiation of the small-scale shear zones is at 
depth, where temperature-controlled rheological weakening mechanisms play an essential role in localizing future shear zones. Thermal heterogeneities of the lithosphere can lead to shear concentration along hot-to-cold contacts ascribed to thermally enhanced rheological weakening. Hence, rheological weakening by heterogeneities may induce strain localization and increase strain rates within magmatic rocks bearing shear zones t(Cao and Neubauer, 2016; Fossen and Cavalcante, 2017; Liu, 2017). The fast strain rate within the high-strain domain of the small-scale shear zone is the consistent geological evidence (Table 1). Thus, the deformation in the small-scale shear zones would be localized to a narrow site through thermal-enhanced rheological weakening mechanisms when GLG-SZ is deformed.

Interestingly, the strain rates gradually decrease from the high-strain $\left(2.85 \times 10^{-13}\right.$ $\left.\mathrm{S}^{-1}\right)$ to the low-strain domain $\left(4.29 \times 10^{-15} \mathrm{~S}^{-1}\right)$ in the small-scale shear zone. It can be explained by the model of shear zone widening during shear deformation (Oliot et al., 2014) after the influence of temperature is eliminated. The center of a shear zone generally presents extreme grain-size reduction, involving fluid-assisted granular flow deformation. The GBS can facilitate fluid migration through shear zones by causing cavities to open and closure, which in turn induces fluids to be pumped through the rock (Fliervoet et al., 1997; Passchier and Trouw, 2005; Kilian et al., 2011; Finch et al., 2016; Menegon et al., 2017; Mansard et al., 2018). This created a pressure gradient, which expelled fluids, leading to hydraulic microfracturing, metasomatism, host rock weakening, and shear zone widening (Oliot et al., 2010, 2014; Finch et al., 2016). In the small-scale shear zone, the localized deformation provoked the release of intracrystalline water to grain boundaries and the migration of water to less deformed rocks, widening the shear zones. Fluid content could restrict weak rheology in the widened shear zone and decrease strain rates. This is also the reason for the grain size stratification of smallscale shear zones (Fig. 11). Field observations and microstructural observations reveal that the kinematic directions of the small-scale shear zone and the continental-scale GLG-SZ are consistent (Fig. 3), reflecting that small-scale shear zones are controlled by the GLG-SZ during progressive deformation and exhumation. The geothermal data demonstrate that the foliated granitic rocks have occurred at least $9 \mathrm{~km}$ of vertical displacement in GLG-SZ. The intrusion depth to the shearing depth may be related to the GLG-SZ tectonic shearing and exhumation (Fig. 10). It also produces a lower temperature condition in granitoids where brittle deformation can occur. Thus, the smallscale shear zone activates as a fault and makes the mafic enclaves cut in the outcropscale (Fig.2G).

\section{Conclusions}

The analyses of meso- and micro-structural, EBSD texture, paleopiezometry, and thermobarometry lead to the following conclusions: 
(1) The small-scale shear zones at the boundary of GLG-SZ have experienced vibrations deformation, mineral composition, and fabric transition from the rim zone of protomylonite to the center zone of ultramylonites, accompanied by a significant grainsize reduction and progressive phase mixing of minerals with an increase in the strain.

(2) The progressive development of microstructures suggests that the ductile deformation of small-scale shear zone is at least amphibolite facies conditions. Rheological weakening due to thermal heterogeneities induces strain localization, resulting in the initiation of the small-scale shear zone.

(3) The deformation mechanism of the coarse-grained aggregate zone in the shear zone is dominated by dislocation creep, while the polyphase fine-grained mixed zone possesses the dominant mechanism of viscous grain boundary sliding. Fluid-assisted deformation plays a crucial role in the hydrous retrogression and subsequent flow rheological weakening of the shear-zone.

(4) The deformation of the small-scale shear zone within the unfoliated granodiorite is controlled by the continental GLG-SZ. The small-scale shear zones experience the same kinematic direction of ductile shearing at depth and during exhumation, as well as the GLG-SZ.

Author contributions: Shuyun Cao and Lefan Zhan planned the overarching research goals and aims; Yanlong Dong, Wenyuan $\mathrm{Li}$ and Lefan Zhan performed the measurements and took the samples; Lefan Zhan analyzed the data; Lefan Zhan wrote the manuscript draft; Shuyun Cao, Yanlong Dong, Wenyuan Li and Lefan Zhan reviewed and edited the manuscript.

Acknowledgments: We gratefully acknowledge Prof. Pennacchioni G. for a lot of discussions and together for field trip. This work was financially supported by National Natural Science Foundations of China (Grant no. 41972220; 4188810) and National Key Research and Development Program (Grant no. 2017YFC0602401) and the Excellent Youth Fund of National Natural Science Foundation of China (Grant no. 41722207).

\section{REFERENCES}

Abers, G.A., van Keken, P.E., Wilson, C.R.: Deep decoupling in subduction zones: Observations and temperature limits, Geosphere, 16, 1408-1424, 2020.

Altenberger, U., Wilhelm, S.: Ductile deformation of K-feldspar in dry eclogite facies shear zones in the Bergen Arcs, Norway, Tectonophysics, 320, 107-121, 2000.

Behrmann, J.H., Seckel, C.: Structures, flow stresses, and estimated strain rates in metamorphic rocks of the Small Cyclades Islands Iraklia and Schinoussa (Aegean Sea, Greece), Geotectonic Research, 95, 1-11, 2007. 
Bense, V.F., Gleeson, T., Loveless, S.E., Bour, O., Scibek, J.: Fault zone hydrogeology, Earth-Sci. Rev., 127, 171-192, 2013.

Bestmann, M., Pennacchioni, G.: Ti distribution in quartz across a heterogeneous shear zone within a granodiorite: The effect of deformation mechanism and strain on Ti resetting, Lithos, 227, 37-56, 2015.

Bhattacharya, A.R., Weber, K.: Fabric development during shear deformation in the Main Central Thrust Zone, NW-Himalaya, India, Tectonophysics, 387, 23-46, 2004.

Bistacchi, A., Massironi, M., Menegon, L.: Three-dimensional characterization of a crustal-scale fault zone: The Pusteria and Sprechenstein fault system (Eastern Alps), J. Struct. Geol., 32, 2022-2041, 2010.

Blundy, J.D., Holland, T.J.B.: Calcic amphibole equilibria and a new amphiboleplagioclase geothermometer, Contrib. Mineral. Petrol., 104, 208-224, 1990.

Bons, P.D., Jessell, M.W.: Micro-shear zones in experimentally deformed octachloropropane, J. Struct. Geol., 21, 323-334, 1999.

Brown, M., Solar, G.S.: Shear-zone systems and melts: feedback relations and selforganization in erogenic belts, J. Struct. Geol., 20, 211-227, 1998.

Cao, S., Liu, J., Leiss, B.: Orientation-related deformation mechanisms of naturally deformed amphibole in amphibolite mylonites from the Diancang Shan, SW Yunnan, China, J. Struct. Geol., 32, 606-622, 2010.

Cao, S., Liu, J., Leiss, B., Neubauer, F., Genser, J., Zhao, C.: Oligo-Miocene shearing along the Ailao Shan-Red River shear zone: Constraints from structural analysis and zircon $\mathrm{U} / \mathrm{Pb}$ geochronology of magmatic rocks in the Diancang Shan massif, SE Tibet, China, Gondwana Res., 19, 975-993, 2011.

Cao, S., Neubauer, F.: Deep crustal expressions of exhumed strike-slip fault systems: Shear zone initiation on rheological boundaries, Earth-Sci. Rev., 162, 155-176, 2016.

Cao, S., Neubauer, F., Bernroider, M., Liu, J.: The lateral boundary of a metamorphic core complex: The Moutsounas shear zone on Naxos, Cyclades, Greece, J. Struct. Geol., 54, 103-128, 2013a.

Cao, S., Neubauer, F., Bernroider, M., Liu, J., Genser, J.: Structures, microfabrics and textures of the Cordilleran-type Rechnitz metamorphic core complex, Eastern Alps, Tectonophysics, 608, 1201-1225, 2013b.

Cao, S., Neubauer, F., Liu, J., Bernroider, M., Cheng, X., Li, J., Yu, Z., Genser, J.: Rheological weakening of high-grade mylonites during low-temperature retrogression: The exhumed continental Ailao Shan-Red River fault zone, SE Asia, J. Asian Earth Sci., 139, 40-60, 2017.

Cavalcante, C., Lagoeiro, L., Fossen, H., Egydio-Silva, M., Morales, L.F.G., Ferreira, F., Conte, T.: Temperature constraints on microfabric patterns in quartzofeldsphatic mylonites, Ribeira belt (SE Brazil), J. Struct. Geol., 115, 243-262, 2018. 
Ceccato, A., Menegon, L., Pennacchioni, G., Morales, L.F.G.: Myrmekite and strain weakening in granitoid mylonites, Solid Earth, 9, 1399-1419, 2018.

Ceccato, A., Goncalves, P., Pennacchioni, G.: Temperature, fluid content and rheology of localized ductile shear zones in subsolidus cooling plutons, J. Metamorph. Geol., 38, 881-903, 2020.

Chen, I.W., Argon, A.S.: Grain boundary and interphase boundary sliding in power law creep, Acta Metallurgica, 27, 749-754, 1979.

Chen, K., Scales, M., Kyriakides, S.: Ductile Failure Under Combined Tension and Shear, Journal of Physics: Conference Series, 1063, 2018.

Cheng, X., Cao, S., Li, J., Yu, Z., Dong, Y., Lv, M., Liu, J.: Metamorphic, deformation, fluids and geological significance of low-temperature retrograde mylonites of Diancangshan metamorphic massif along Ailaoshan-Red River strike-slip fault zone, Yunnan, China, Sci. China-Earth Sci., 61, 1023-1041, 2018.

Chiu, Y.P., Yeh, M.W., Wu, K.H., Lee, T.Y., Lo, C.H., Chung, S.L., Iizuka, Y.: Transition from extrusion to flow tectonism around the Eastern Himalaya syntaxis, Geol. Soc. Am. Bull., 130, 1675-1696, 2018.

Collettini, C., Niemeijer, A., Viti, C., Marone, C.: Fault zone fabric and fault weakness, Nature, 462, 907-910, 2009.

Cunningham, W.D., Mann, P.: Tectonics of strike-slip restraining and releasing bends, Geological Society, London, Special Publications, 290, 1-12, 2007.

Czaplińska, D., Piazolo, S., Zibra, I.: The influence of phase and grain size distribution on the dynamics of strain localization in polymineralic rocks, J. Struct. Geol., 72, 15 $32,2015$.

Dang, J., Zhou, Y., Rybacki, E., He, C., Dresen, G.: An experimental study on the brittleplastic transition during deformation of granite, J. Asian Earth Sci., 139, 30-39, 2017.

Dayem, K.E., Houseman, G.A., Molnar, P.: Localization of shear along a lithospheric strength discontinuity: Application of a continuous deformation model to the boundary between Tibet and the Tarim Basin, Tectonics, 28, n/a-n/a, 2009.

Dong, Y., Cao, S., Cheng, X., Liu, J., Cao, H.: Grain-size reduction of feldspar and flow of deformed granites within the Gaoligong shear zone, southwestern Yunnan, China, Sci. China-Earth Sci., 62, 1379-1398, 2019.

Dong, Y., Cao, S., Neubauer, F., Wang, H., Li, W., Genser, J.: Exhumation of the crustalscale Gaoligong strike-slip shear belt in Southeast Asia, J. Geol. Soc., 2021.

Drury, M.R., Humphreys, F.J.: Microstructural shear criteria associated with grainboundary sliding during ductile deformation, J. Struct. Geol., 10, 83-89, 1988.

Egydio-Silva, M., Vauchez, A., Bascou, J., Hippertt, J.: High-temperature deformation in the Neoproterozoic transpressional Ribeira belt, southeast Brazil, Tectonophysics, 352, 203-224, 2002. 
Evans, D.M.: Kabanga magmatic nickel sulphide deposits, Tanzania: morphology and geochemistry of associated intrusions, J. Afr. Earth Sci., 30, 651-674, 2000.

Fagereng, A., Beall, A.: Is complex fault zone behaviour a reflection of rheological heterogeneity, Philos Trans A Math Phys Eng Sci 379, 20190421, 2021.

Faulkner, D.R., Rutter, E.H.: Can the maintenance of overpressured fluids in large strikeslip fault zones explain their apparent weakness, Geology, 29, 2001.

Finch, M.A., Weinberg, R.F., Hunter, N.J.R.: Water loss and the origin of thick ultramylonites, Geology, 44, 599-602, 2016.

Fliervoet, T.F., White, S.H., Drury, M.R.: Evidence for dominant grain-boundary sliding deformation in greenschist- and amphibolite-grade polymineralic ultramylonites from the Redbank Deformed Zone, Central Australia, J. Struct. Geol., 19, 1495-1520, 1997.

Fossen, H., Cavalcante, G.C.G.: Shear zones-A review, Earth-Sci. Rev., 171, 434-455, 2017.

Franěk, J., Schulmann, K., Lexa, O.: Kinematic and rheological model of exhumation of high pressure granulites in the Variscan orogenic root: example of the Blanský les granulite, Bohemian Massif, Czech Republic, Mineral. Petrol., 86, 253-276, 2006.

Frost, E., Dolan, J., Ratschbacher, L., Hacker, B., Seward, G.: Direct observation of fault zone structure at the brittle-ductile transition along the Salzach-Ennstal-MariazellPuchberg fault system, Austrian Alps, J. Geophys. Res., 116, 2011.

Fusseis, F., Regenauer-Lieb, K., Liu, J., Hough, R.M., De Carlo, F.: Creep cavitation can establish a dynamic granular fluid pump in ductile shear zones, Nature, 459, 974977, 2009.

Ganade de Araujo, C.E., Weinberg, R.F., Cordani, U.G.: Extruding the Borborema Province (NE-Brazil): a two-stage Neoproterozoic collision process, Terr. Nova, 26, 157-168, 2014.

Gandais, M., Willaime, C.: Mechanical Properties of Feldspars, Feldspars and Feldspathoids: Structures, Properties and Occurrences, 1st ed. Springer, Netherland, pp. 207-246, 1984.

Gibert, B., Mainprice, D.: Effect of crystal preferred orientations on the thermal diffusivity of quartz polycrystalline aggregates at high temperature, Tectonophysics, 465, 150-163, 2009.

Gower, R.J.W., Simpson, C.: Phase boundary mobility in naturally deformed, high-grade quartzofeldspathic rocks: evidence for diffusional creep, J. Struct. Geol., 14, 301 313, 1992.

Handy, M.R.: Deformation regimes and the rheological evolution of fault zones in the lithosphere: the effects of pressure, temperature, grain size and time, Tectonophysics, 163, 119-152, 1989. 
Hanmer, S.: Great Slave Lake Shear Zone, Canadian Shield: reconstructed vertical profile of a crustal-scale fault zone, Tectonophysics, 149, 245-264, 1988.

Hansen, L.N., Cheadle, M.J., John, B.E., Swapp, S.M., Dick, H.J.B., Tucholke, B.E., Tivey, M.A.: Mylonitic deformation at the Kane oceanic core complex: Implications for the rheological behavior of oceanic detachment faults, Geochem. Geophys. Geosyst., 14, 3085-3108, 2013.

Heidelbach, F., Post, A., Tullis, J.: Crystallographic preferred orientation in albite samples deformed experimentally by dislocation and solution precipitation creep, J. Struct. Geol., 22, 1649-1661, 2000.

Hippertt, J., Rocha, A., Lana, C., Egydio-Silva, M., Takeshita, T.: Quartz plastic segregation and ribbon development in high-grade striped gneisses, J. Struct. Geol., 23, 67-80, 2001.

Hippertt, J.F.: Breakdown of feldspar, volume gain and lateral mass transfer during mylonitization of granitoid in a low metamorphic grade shear zone, J. Struct. Geol., 20, 175-193, 1998.

Hirth, G., Teyssier, C., Dunlap, J.W.: An evaluation of quartzite flow laws based on comparisons between experimentally and naturally deformed rocks, Int. J. Earth Sci., 90, 77-87, 2001.

Hirth, G., Tullis, J.: Dislocation creep regimes in quartz aggregates, J. Struct. Geol., 14, 145-159, 1992.

Hobbs, B.: The Geological Significance of Microfabric Analysis, Preferred Orientation in Deformed Metals and Rocks: An Introduciton to Modern Texture Analysis, pp. 463-484, 1985.

Holland, T., Blundy, J.: Non-ideal interactions in calcic amphiboles and their bearing on amphibole-plagioclase thermometry, Contrib. Mineral. Petrol., 116, 433-447, 1994.

Hollister, L.S., Grissom, G.C., Peters, E.K., Stowell, H.H., Gisson, V.B.: Confirmation of the empirical correlation of $\mathrm{Al}$ in hornblende with pressure of solidification of calc-alkaline plutons, Am. Miner., 72, 231-239, 1987.

Holyoke, C.W., Tullis, J.: Formation and maintenance of shear zones, Geology, 34, 2006.

Imber, I., Holdsworth, R.E., Butler, C.A., Lloyd, G.E.: Fault-zone weakening processes along the reactivated Outer Hebrides Fault Zone, Scotland, J. Geol. Soc., 154, 105109, 1997.

Ishii, K., Kanagawa, K., Shigematsu, N., Okudaira, T.: High ductility of K-feldspar and development of granitic banded ultramylonite in the Ryoke metamorphic belt, SW Japan, J. Struct. Geol., 29, 1083-1098, 2007.

Luan, F.C., Paterson, M.S.: Preparation and deformation of synthetic aggregates of quartz, J. Geophys. Res 97, 301-320, 1992.

Ji, J., Zhong, D., Sang, H., Zhang, L.: The western boundary of extrusion blocks in the 
southeastern Tibetan Plateau, Chin. Sci. Bull., 876-881, 2000a.

Ji, J., Zhong, D., Shang, H., Qiu, J., Hu, S.: Dating of two metamorphic events on the basalt granulite from Nabang area on the border of China and Burma, Acta Petrol. Sin., 16, 227-232, 2000b.

Kilian, R., Heilbronner, R., Stünitz, H.: Quartz grain size reduction in a granitoid rock and the transition from dislocation to diffusion creep, J. Struct. Geol., 33, 1265-1284, 2011.

Kohlstedt, D.: The Role of Water in High-Temperature Rock Deformation, Reviews in Mineralogy \& Geochemistry, Mineralogical Society of America, Washington, D.C., pp. 377-396, 2006.

Kronenberg, A.K.: Hydrogen speciation and chemical weakening of quartz, Reviews in Mineralogy, 29, 123-176, 1994.

Kruhl, J.H.: Preferred lattice orientations of plagioclase from amphibolite and greenschist facies rocks near the lnsubric Line (Western Alps), Tectonophysics, 135, 233-242, 1987.

Kruse, R., StuÈnitz, H., Kunze, K.: Dynamic recrystallization processes in plagioclase porphyroclasts, J. Struct. Geol., 23, 1781-1802, 2001.

Langdon, T.G.: Grain boundary sliding revisited: Developments in sliding over four decades, J. Mater. Sci., 41, 597-609, 2006.

Liu, J.L.: Strain localization and strain weakening in the continental middle crust, Acta Petrol. Sin., 33, 1653-1666, 2017.

Liu, Z., Ji, J., Sa, X., Chen, Y., Zhong, D.: Crustal deformation and tectonic levels of Nujiang Gorge since the Miocene, Sci. China-Earth Sci., 61, 93-108, 2017.

Mainprice, D., Bouchez, J.-L., Blumenfeld, P., Tubiâ, J.M.: Dominant c slip in naturally deformed quartz: Implications for dramatic plastic softening at high temperature, Geology, 14, 819-822, 1986.

Mancktelow, N.S.: Finite-element modelling of shear zone development in viscoelastic materials and its implications for localisation of partial melting, J. Struct. Geol., 24, 1045-1053, 2002.

Mancktelow, N.S.: Tectonic pressure: Theoretical concepts and modelled examples, Lithos, 103, 149-177, 2008.

Mancktelow, N.S., Pennacchioni, G.: The influence of grain boundary fluids on the microstructure of quartz-feldspar mylonites, J. Struct. Geol., 26, 47-69, 2004.

Mancktelow, N.S., Pennacchioni, G.: The control of precursor brittle fracture and fluidrock interaction on the development of single and paired ductile shear zones, J. Struct. Geol., 27, 645-661, 2005.

Mancktelow, N.S., Pennacchioni, G.: Late magmatic healed fractures in granitoids and their influence on subsequent solid-state deformation, J. Struct. Geol., 57, 81-96, 
Mancktelow, N.S., Pennacchioni, G.: Intermittent fracturing in the middle continental crust as evidence for transient switching of principal stress axes associated with the subduction zone earthquake cycle, Geology, 48, 1072-1076, 2020. Armorican massif, Tectonophysics, 745, 46-65, 2018.

Martelat, J.-E., Schulmann, K., Lardeaux, J.-M., Nicollet, C., Cardon, H.: Granulite microfabrics and deformation mechanisms in southern Madagascar, J. Struct. Geol., 21, 671-687, 1999.

Menegon, L., Pennacchioni, G.: Local shear zone pattern and bulk deformation in the Gran Paradiso metagranite (NW Italian Alps), Int. J. Earth Sci., 99, 1805-1825, 2009.

Menegon, L., Pennacchioni, G., Malaspina, N., Harris, K., Wood, E.: Earthquakes as Precursors of Ductile Shear Zones in the Dry and Strong Lower Crust, Geochem. Geophys. Geosyst., 18, 4356-4374, 2017.

Menegon, L., Pennacchioni, G., Spiess, R.: Dissolution-precipitation creep of K-feldspar in mid-crustal granite mylonites, J. Struct. Geol., 30, 565-579, 2008.

Miranda, E.A., Hirth, G., John, B.E.: Microstructural evidence for the transition from dislocation creep to dislocation-accommodated grain boundary sliding in naturally deformed plagioclase, J. Struct. Geol., 92, 30-45, 2016.

Misra, S., Mandal, N.: Localization of plastic zones in rocks around rigid inclusions: Insights from experimental and theoretical models, J. Geophys. Res., 112, 2007.

Montardi, Y., Mainprice, D.: A transmission electron microscopic study of the natural plastic deformation of calcific plagioclases (AN-68-70), Bulletin De Mineralogie, 110, 1-14, 1987.

Morley, C.K.: Variations in Late Cenozoic-Recent strike-slip and oblique-extensional geometries, within Indochina: The influence of pre-existing fabrics, J. Struct. Geol., 29, 36-58, 2007.

Morrow, C., Solum, J., Tembe, S., Lockner, D., Wong, T.F.: Using drill cutting separates to estimate the strength of narrow shear zones at SAFOD, Geophys. Res. Lett., 34, 2007.

Nevitt, J.M., Pollard, D.D.: Impacts of off-fault plasticity on fault slip and interaction at the base of the seismogenic zone, Geophys. Res. Lett.,, 2017.

Nevitt, J.M., Warren, J.M., Pollard, D.D.: Testing constitutive equations for brittleductile deformation associated with faulting in granitic rock, J. Geophys. Res.,: Solid Earth 122, 6269-6293, 2017.

Oliot, E., Goncalves, P., Marquer, D.: Role of plagioclase and reaction softening in a metagranite shear zone at mid-crustal conditions (Gotthard Massif, Swiss Central 
Alps), J. Metamorph. Geol., 28, 849-871, 2010.

Oliot, E., Goncalves, P., Schulmann, K., Marquer, D., Lexa, O.: Mid-crustal shear zone formation in granitic rocks: Constraints from quantitative textural and crystallographic preferred orientations analyses, Tectonophysics, 612-613, 63-80, 2014.

Olsen, T.S., Kohlstedt, D.L.: Analysis of Dislocations in Some Naturally Deformed Plagioclase Feldspars, Phys. Chem. Miner., 11, 153-160, 1984.

Olsen, T.S., Kohlstedt, D.L.: Natural deformation and recrystallization of some intermediate plagioclase feldspars, Tectonophysics, 111, 107-131, 1985.

Oriolo, S., Wemmer, K., Oyhantçabal, P., Fossen, H., Schulz, B., Siegesmund, S.: Geochronology of shear zones - A review, Earth-Sci. Rev., 185, 665-683, 2018.

Otani, M., Wallis, S.: Quartz lattice preferred orientation patterns and static recrystallization: Natural examples from the Ryoke belt, Japan, Geology, 34, 2006.

Passchier, C.W., Trouw, R.A.J.: Microtectonics, 2nd ed, Springer, Berlin, 2005.

Pennacchioni, G.: Control of the geometry of precursor brittle structures on the type of ductile shear zone in the Adamello tonalites, Southern Alps (Italy), J. Struct. Geol., 27, 627-644, 2005.

Pennacchioni, G., Mancktelow, N.S.: Small-scale ductile shear zones: Neither extending, nor thickening, nor narrowing, Earth-Sci. Rev., 184, 1-12, 2018.

Pennacchioni, G., Zucchi, E.: High temperature fracturing and ductile deformation during cooling of a pluton: The Lake Edison granodiorite (Sierra Nevada batholith, California), J. Struct. Geol., 50, 54-81, 2013.

Platt, J.P.: Rheology of two-phase systems: A microphysical and observational approach, J. Struct. Geol., 77, 213-227, 2015.

Popp, R.K., Virgo, D., Yoder, H.S., Hoering, T.C., Phillips, M.W.: An experimental study of phase equilibria and $\mathrm{Fe}$ oxy-component in kaersutitic amphibole: Implications for the $\mathrm{f}_{\mathrm{H} 2}$ and $\mathrm{a}_{\mathrm{H} 20}$ in the upper mantle, Am. Miner., 80, 534-548, 1995.

Precigout, J., Prigent, C., Palasse, L., Pochon, A.: Water pumping in mantle shear zones, Nat. Commun., 8, 15736, 2017.

Précigout, J., Stünitz, H.: Evidence of phase nucleation during olivine diffusion creep: A new perspective for mantle strain localisation, Earth Planet. Sci. Lett., 455, 94-105, 2016.

Ratschbacher, L., Merle, O., Davy, P. and Cobbold, P.: Lateral extrusion in the Eastern Alps, Part 1: Boundary conditions and experiments scaled for gravity, Tectonics, 10, 245-256, 1991.

Ridolfi, F., Renzulli, A.: Calcic amphiboles in calc-alkaline and alkaline magmas: thermobarometric and chemometric empirical equations valid up to $1,130^{\circ} \mathrm{C}$ and 2.2 GPa, Contrib. Mineral. Petrol., 163, 877-895, 2011. 
Rosenberg, C.L.: Shear zones and magma ascent: A model based on a review of the Tertiary magmatism in the Alps, Tectonics, 23, n/a-n/a, 2004.

Schmid, S.M., Casey, M.: Complete fabric analysis of some commonly observed quartz C-axis patterns, Mineral and Rock Deformation: Laboratory Studies, pp. 263-286, 1986.

Schmid, S.M., Pfiffner, O.A., Froitzheim, N., Schönborn, G., Kissling, E.: Geophysicalgeological transect and tectonic evolution of the Swiss-Italian Alps, Tectonics, 15, 1036-1064, 1996.

Schmidt, M.W.: Amphibole composition in tonalite as a function of pressure: an experimental calibration of the Al-in-hornblende barometer, Contrib. Mineral. Petrol., 110, 304-310, 1992.

Scholz, C.H.: Shear heating and the state of stress on faults, J. Geophys. Res.-Solid Earth, 85, 6174-6184, 1980.

Scholz, C.H.: Mechanics of faulting, Annu. Rev. Earth Planet. Sci., 17, 309-334, 1989.

Searle, M.P., Yeh, M.W., Lin, T.H., Chung, S.L.: Structural constraints on the timing of left-lateral shear along the Red River shear zone in the Ailao Shan and Diancang Shan Ranges, Yunnan, SW China, Geosphere, 6, 316-338, 2010.

Sibson, R.H.: Fault rocks and fault mechanisms, J. Geol. Soc., 133, 191-213, 1977.

Spruzeniece, L., Piazolo, S.: Strain localization in brittle-ductile shear zones: fluid abundant vs fluid limited conditions (an example from Wyangala area, Australia), Solid Earth, 7, 1399-1446, 2015.

Stein, E., Dietl, C.: Hornblende thermobarometry of granitoids from the Central Odenwald (Germany) and their implications for the geotectonic development of the Odenwald, Mineral. Petrol., 72, 185-207, 2001.

Stipp, M., StuÈnitz, H., Heilbronner, R., Schmid, S.M.: The eastern Tonale fault zone: a 'natural laboratory' for crystal plastic deformation of quartz over a temperature range from 250 to $700{ }^{\circ} \mathrm{C}$, J. Struct. Geol., 24, 1861-1884, 2002.

Stipp, M., Tullis, J.: The recrystallized grain size piezometer for quartz, Geophys. Res. Lett., 30, 2003.

Stünitz, H., Fitz Gerald, J.D., Tullis, J.: Dislocation generation, slip systems, and dynamic recrystallization in experimentally deformed plagioclase single crystals, Tectonophysics, 372, 215-233, 2003.

Stünitz, H., J.D., F.G.: Deformation of granitoids at low metamorphic grade II: Granular flow in albite-rich mylonites, Tectonophysics, 221, 299-324, 1993.

Tang, Y., Wang, D., Liao, S., Wang, B., Yin, F.: Fabrics and 40Ar/39Ar ages of metamorphic rocks in the Gaoligong tectonic belt: Implications for Cenozoic metamorphism and deformation in the SE Tibetan Plateau, J. Asian Earth Sci., 192, 2020 . 
Tapponnier, P., Molnar, P.: Active faulting and tectonics of China, J. Geophys. Res., 82, 2905-2930, 1977.

Tapponnier, P., Peltzer, G., Armijo, R., Le Dain, A.Y., Cobbold, P.: Propagating extrusion tectonics in Asia: new insights from simple experiments with plasticine, Geology, 10, 611-616, 1982.

Tapponnier, P., Lacassin, R., Leloup, P.H., Schärer, U., Zhong, D.L., Liu, X.H., Ji, S.C., Zhang, L.S., Zhong, J.Y.: The Ailao Shan/Red River metamorphic belt: Tertiary leftlateral shear between Indochina and South China, Nature, 343, 431-437, 1990.

Tikoff, B., de Saint Blanquat, M.: Transpressional shearing and strike-slip partitioning in the Late Cretaceous Sierra Nevada magmatic arc, California, Tectonics, 16, 442 459, 1997.

Toy, V.G., Prior, D.J., Norris, R.J.: Quartz fabrics in the Alpine Fault mylonites: Influence of pre-existing preferred orientations on fabric development during progressive uplift, J. Struct. Geol., 30, 602-621, 2008.

Tribe, I.R., D'Lemos, R.S.: Significance of a hiatus in down-temperature fabric development within syntectonic quartz diorite complexes, Channel Islands, UK, J. Geol. Soc., 153, 127-138, 1996.

Tullis, J., Wenk, H.R.: Effect of muscovite on the strength and lattice preferred orientations of experimentally deformed quartz aggregates, Mater. Sci. Eng. A-Struct. Mater. Prop. Microstruct. Process., 175, 209-220, 1994.

Tullis, J., Yund, R.A.: Transition from cataclastic flow to dislocation creep of feldspar: Mechanisms and microstructures, Geology, 15, 606-609, 1987.

Tullis, J., Yund, R.A.: Diffusion creep in feldspar aggregates: experimental evidence, J. Struct. Geol., 13, 987-1000, 1991.

Twiss, R.J.: Static theory of size variations with stress for subgrains and dynamically recrystallized grains, U.S.G.S, Open-file Report, pp. 665-683, 1980.

Vannucchi, P.: Scaly fabric and slip within fault zones, Geosphere, 15, 342-356, 2019.

Vauchez, A.: Egydio-Silva, M., Babinski, M., Tommasi, A., Uhlein, A., Liu, D., Deformation of a pervasively molten middle crust: insights from the neoproterozoic Ribeira-Araçuaí orogen (SE Brazil), Terr. Nova, 19, 278-286, 2007.

Wang, W., Song, Z., Tang, Y., Chen, X., Liu, J.: The Ailao Shan-Red River shear zone revisited: Timing and tectonic implications, Geol. Soc. Am. Bull., 132, 1165-1182, 2019.

Wang, Y., Fan, W., Zhang, Y., Peng, T., Chen, X., Xu, Y.: Kinematics and 40Ar/39Ar geochronology of the Gaoligong and Chongshan shear systems, western Yunnan, China: Implications for early Oligocene tectonic extrusion of SE Asia, Tectonophysics, 418, 235-254, 2006.

Wehrens, P., Berger, A., Peters, M., Spillmann, T., Herwegh, M.: Deformation at the 
frictional-viscous transition: Evidence for cycles of fluid-assisted embrittlement and ductile deformation in the granitoid crust, Tectonophysics, 693, 66-84, 2016.

White, S.H., Knipe, R.J.: Transformation- and reaction-enhanced ductility in rocks, J. Geol. Soc., 135, 513-516, 1978.

Wibberley, C.A.J., Yielding, G., Di Toro, G.: Recent advances in the understanding of fault zone internal structure: a review, Geological Society, London, Special Publications, 299, 5-33, 2008.

Wintsch, R.P., Christoffersen, R., Kronenberg, A.K.: Fluid-rock reaction weakening of fault zones, J. Geophys. Res.-Solid Earth, 100, 13021-13032, 1995.

Wintscha, R.P., Yi, K.: Dissolution and replacement creep: a significant deformation mechanism in mid-crustal rocks, J. Struct. Geol., 24, 1179-1193, 2002.

Wirth, R., Voll, G.: Cellular intergrowth between quartz and sodium-rich plagioclase (myrmekite) - an analogue of discontinuous precipitation in metal alloys, J. Mater. Sci., 22, 1913-1918, 1987.

Wise, D.U., Dunn, D.E., Engelder, J.T., Geiser, P.A., Hatcher, R.D., Kish, S.A., Odom, A.L., Schamel, S.: Fault-related rocks: Suggestions for terminology, Geology, 12, 391-394, 1984.

Xia, H.R., Liu, J.L.: The crystallographic preferred orientation of quartz and its applications, Chin. Sci. Bull., 30, 58-70, 2011.

Xu, Y.G., Yang, Q.J., Lan, J.B., Luo, Z.Y., Huang, X.L., Shi, Y.R., Xie, L.W.: Temporalspatial distribution and tectonic implications of the batholiths in the GaoligongTengliang-Yingjiang area, western Yunnan: Constraints from zircon $\mathrm{U}-\mathrm{Pb}$ ages and Hf isotopes, J. Asian Earth Sci., 53, 151-175, 2012.

Xu, Z., Wang, Q., Cai, Z., Dong, H., Li, H., Chen, X., Duan, X., Cao, H., Li, J., Burg, J.P.: Kinematics of the Tengchong Terrane in SE Tibet from the late Eocene to early Miocene: Insights from coeval mid-crustal detachments and strike-slip shear zones, Tectonophysics, 665, 127-148, 2015.

Yamasaki, T., Wright, T.J., Houseman, G.A.: Weak ductile shear zone beneath a major strike-slip fault: Inferences from earthquake cycle model constrained by geodetic observations of the western North Anatolian Fault Zone, J. Geophys. Res.-Solid Earth, 119, 3678-3699, 2014.

Zhang, B., Chai, Z., Yin, C.Y., Huang, W.T., Wang, Y., Zhang, J.J., Wang, X.X., Cao, K.: Intra-continental transpression and gneiss doming in an obliquely convergent regime in SE Asia, J. Struct. Geol., 97, 48-70, 2017.

Zhang, B., Zhang, J., Chang, Z., Wang, X., Cai, F., Lai, Q.: The Biluoxueshan transpressive deformation zone monitored by synkinematic plutons, around the Eastern Himalayan Syntaxis, Tectonophysics, 574-575, 158-180, 2012a.

Zhang, B., Zhang, J., Zhong, D., Yang, L., Yue, Y., Yan, S.: Polystage deformation of the 
1219 Gaoligong metamorphic zone: Structures, 40Ar/39Ar mica ages, and tectonic 1220 implications, J. Struct. Geol., 37, 1-18, 2012b.

1221 Zhang, J., Peng, T., Fan, W., Zhao, G., Dong, X., Gao, J., Peng, B., Wei, C., Xia, X., Chen, L., Liang, X.: Petrogenesis of the Early Cretaceous granitoids and its mafic enclaves in the Northern Tengchong Terrane, southern margin of the Tibetan Plateau and its tectonic implications, Lithos, 318-319, 283-298, 2018.

Zhu, R.Z., Lai, S.C., Qin, J.F., Zhao, S.W., Wang, J.B.: Late Early-Cretaceous quartz diorite-granodiorite-monzogranite association from the Gaoligong belt, southeastern Tibet Plateau: Chemical variations and geodynamic implications, Lithos, 288-289, 311-325, 2017. 